\title{
Graves' disease: introducing new genetic and epigenetic contributors
}

\author{
Ehsan Razmara ${ }^{1,2}$, Mehrnaz Salehi3, Saeed Aslani1 ${ }^{1}$, Amirreza Bitaraf1,4, Hassan Yousefi ${ }^{5}$, Jonathan Rosario Colón ${ }^{5}$ \\ and Mahdi Mahmoudi1,6
}

${ }_{1}^{1}$ Rheumatology Research Center, Tehran University of Medical Sciences, Tehran, Iran ${ }^{2}$ Australian Regenerative Medicine Institute, Monash University, Clayton, Australia ${ }^{3}$ School of Medicine, Shahrekord University of Medical Science, Shahrekord, Iran ${ }^{4}$ Department of Molecular Genetics, Faculty of Biological Sciences, Tarbiat Modares University, Tehran, Iran ${ }^{5}$ Department of Biochemistry and Molecular Biology, LSUHSC School of Medicine, New Orleans, Louisiana, USA ${ }^{6}$ Inflammation Research Center, Tehran University of Medical Sciences, Tehran, Iran

Correspondence should be addressed to M Mahmoudi: mahmoudim@tums.ac.ir

\begin{abstract}
Autoimmune thyroid disease (AITD) accounts for $90 \%$ of all thyroid diseases and affects $2-5 \%$ of the population with remarkable familial clustering. Among AITDs, Graves' disease (GD) is a complex disease affecting thyroid function. Over the last two decades, casecontrol studies using cutting-edge gene sequencing techniques have detected various susceptible loci that may predispose individuals to GD. It has been presumed that all likely associated genes, variants, and polymorphisms might be responsible for $75-80 \%$ of the heritability of GD. As a result, there are implications concerning the potential contribution of environmental and epigenetic factors in the pathogenesis of GD, including its initiation, progression, and development. Numerous review studies have summarized the contribution of genetic factors in GD until now, but there are still some key questions and notions that have not been discussed concerning the interplay of genetic, epigenetic, and immunological factors. With this in mind, this review discusses some newly-identified loci and their potential roles in the pathogenicity of GD. This may lead to the identification of new, promising therapeutic targets. Here, we emphasized principles, listed all the reported disease-associated genes and polymorphisms, and also summarized the current understanding of the epigenetic basis of GD.
\end{abstract}

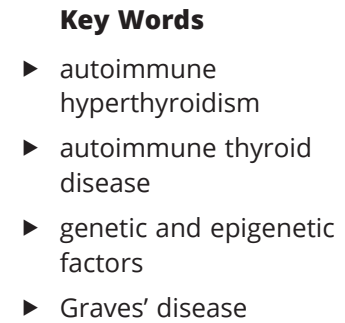

Journal of Molecular Endocrinology (2021) 66, R33-R55

\section{Introduction}

Graves' disease (GD) causes hyperthyroidism as a result of circulating IgG antibodies that activate the thyroidstimulating hormone receptor (TSHR). This activation leads to follicular hypertrophy/hyperplasia, which in turn causes thyroid enlargement and augments thyroid hormone production, especially the ratio of triiodothyronine (T3) relative to thyroxine (T4) in thyroid secretions. Thyroid-function testing in GD shows typically low basal serum TSH levels that are followed by a high level of free T3 and T4 in serum (Brent 2008).

A combination of genetic, epigenetic, and environmental factors can account for autoimmune responses against the thyroid gland (Imani et al. 2017). These responses are limited to lymphocytic infiltration and autoantibodies targeting thyroid antigens, such as TSHR, thyroglobulin (TG), and thyroid peroxidase (TPO). 
T cells recognize various epitopes of the TSHR and induce B cells to secrete thyroid-stimulating antibodies. The uncontrolled thyroid hormone production and ensued hyperthyroidism are caused by mimicking the action of TSH through TSHR-stimulating autoantibodies.

Hereditary factors have been demonstrated to account for $75-80 \%$ of the risk of GD development (Khalilzadeh et al. 2009, Anvari et al. 2010). The incidence of GD is about 20 to 50 cases per 100,000 people and individuals can be affected at any age, but usually between 30 and 50 years (Zimmermann et al. 2015). Concordance among monozygotic twins is higher in comparison with dizygotic twins and the male-to-female ratio among patients with GD is between 1:5 and 1:10 (Zhao et al. 2019). Recent studies have shown the roles of interacting risk factors as in genetics, immunogenetics, epigenetics, and environmental factors. In the following, we discuss some essential genetic and epigenetic factors that play substantial roles in GD. We summarize and list the genes according to the functions in two distinct groups: Thyroid hormone synthesis and $\mathrm{T}$ cell response regulatory genes. We also enumerate variants/polymorphisms that are associated with heightened or decreased GD susceptibility. Ultimately, we focus on epigenetic factors and their possible roles in GD development.

\section{Thyroid hormone synthesis}

Besides its undeniable roles in the immune system, the main function of the thyroid gland is synthesizing T3 and $\mathrm{T} 4$ hormones that are essential for the regulation of metabolic processes. This process initiates with thyroglobulin synthesis and its secretion into the follicular lumen followed by iodine transportation and oxidation that lead to the iodination of thyroglobulin tyrosine residues. After endocytosis, lysosomes can hydrolyze the complex and prepare the secretion of T3 and T4. Each of these complex processes can be modulated by encoded proteins of TSHR, TPO, and TG (Fig. 1A). In the following, the roles of these genes in the immune system will be highlighted.

\section{TSH receptor}

The TSHR was a critical candidate for GD (Tonacchera \& Pinchera 2000). To date, numerous SNPs associated with GD risk have been identified (Table 1). TSHR antibodies are present in GD patients and are directly related to disease severity (Tomer 2014). The most causative variants are located within intron 1 (Tomer et al. 2013) that probably change the splicing process. These variants downregulate TSHR in the thymus by developing autoreactive TSHRtargeting $\mathrm{T}$ cells that have escaped deletion. Regarding this, we can propose two possible mechanisms: peripheral and central tolerance.

According to peripheral tolerance, after TSHR expression, the protein undergoes different modifications such as glycosylation, dimerization, sulfation, disulfidebond formation, and proteolytic cleavage (Rapoport \& McLachlan 2007). The TSHR may undergo posttranslational intramolecular cleavage of its $\mathrm{A}$ and $\mathrm{B}$ subunits which determines its fate: A subunit forms a large extracellular domain, while the B subunit sets up the seven-transmembrane domain. Several alternatively spliced variants in the TSHR gene have been detected that can change the balanced expression of these subunits (Table 1) (Brand et al. 2009). There is also evidence for up to 5 truncated TSHR transcripts, particularly ST4 $(1.3 \mathrm{~Kb})$ and ST5 $(1.7 \mathrm{~Kb})$, that encode a significant percentage of the entire ligand-binding extracellular region (Fig. 1B). The truncated mRNA transcripts ST4 and ST5 encode the majority of soluble A-subunit directly, hence increasing the chances of autoantibody production against the TSHR. Different polymorphisms, for example, rs179247 and rs12101255, have been reported in association with the production of the soluble A subunit (Colobran et al. 2011) (Table 1). In sum, the generation of this soluble form of TSHR can likely favor an autoimmune response, although the molecular mechanism is not clear.

The expression of self-antigens in the thymus is essential for 'Central Tolerance'. These antigens vividly play in a negative selection of autoreactive $\mathrm{T}$ cell clones. This process filters developing $\mathrm{T}$ and $\mathrm{B}$ cells and eliminates auto-reactive lymphocytes (Fig. 2). In medullary thymic epithelial cells, tissue-restricted autoantigens can induce the expression of promiscuous gene expression (PGE), providing various ligands that are vital for the negative selection of $\mathrm{T}$ cells. Genetic variations in the autoimmune-related genes, for example, AIRE gene, can also influence the expression of PGE and TSHR (Mathis \& Benoist 2009). Hence, it seems fair to suggest that DNA alternations that affect central tolerance can change the TSHR signaling in GD.

Two mapped SNPs the intron 1 of the TSHR, rs12101255 and rs12101261, have an association with GD via epigenetic functions. Interferon- $\alpha$ (IFn- $\alpha$ ) leads to a remarkable H3K4me1 enrichment only in the overlapping region of rs12101255 and rs1210126, proposing one of them is the causative SNP. Furthermore, a regulatory element has been identified that binds to 
A

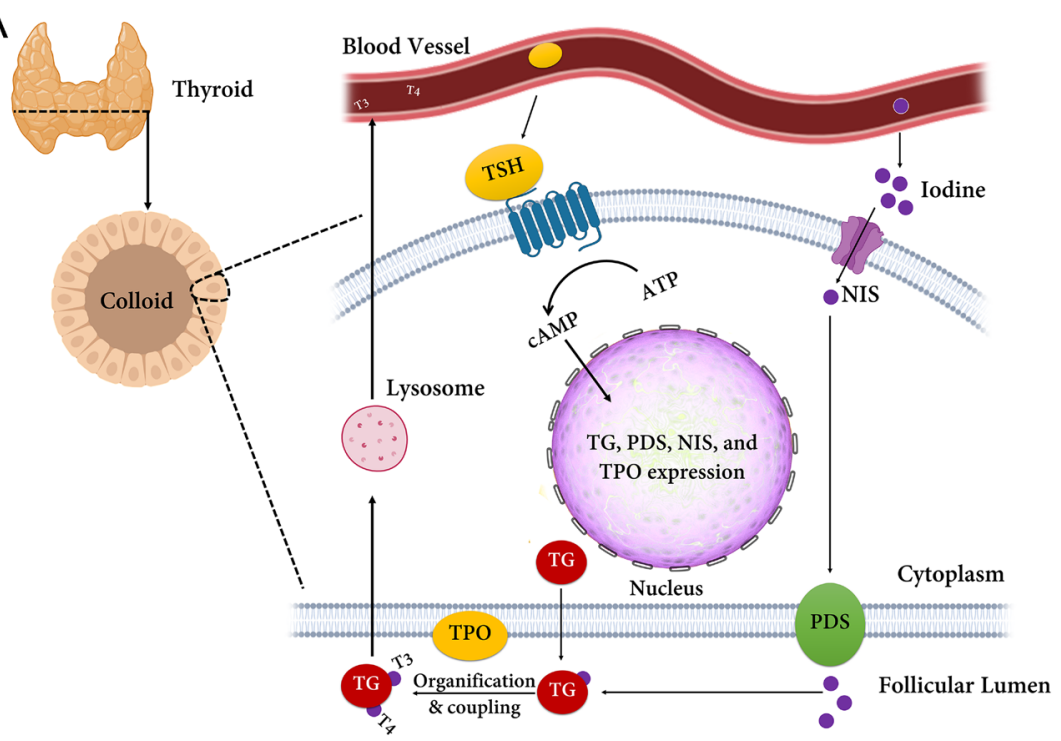

\section{Figure 1}

(A) Thyroid hormone synthesis (reviewed in Kopp \& Solis-S 2009). Thyrotropin (TSH) as the main stimulator of TSHR can transduce the signal through cAMP production in the cytoplasm, which in turn can modulate thyroid hormone-

responsive gene expression, for example, $T P O, T G$, sodium-iodide symporter (NIS), and pendrin (PDS). This figure introduces a pathway that includes TSHR, TPO, and TG. The figure is redrawn from Galligan et al. (2019). (B) Structure of the TSHR gene. This gene contains 10 exons and encodes a protein in a full-length version with 764 amino acids. The TSHR gene is transcribed to a full-length mRNA (fITSHR or TSH holoreceptor) and 2 main splicing isoform including ST4 and ST5. ST4 and ST5 are common in at the first 8 exons but differ in an additional unique 9 th exon. These unique exons are highlighted in green and red. In the figure, C, C-terminal; N, N-terminal region; SP, signal peptide; LRR, leucine-rich repeat; TMD, transmembrane domain; CM, Cytoplasmic Motifs. In GD patients, LRRs are a subject of pathogenic stimulating antibodies. The figure is redrawn from Marín-Sánchez et al. (2019). A full color version of this figure is available at https://doi. org/10.1530/JME-20-0078.

the transcriptional repressor region of the promyelocytic leukemia zinc finger (PLZF) in the rs12101261 location. This polymorphism reduces the expression of PLZF in GD patients (Chen et al. 2018). TSHR expression was also reduced intrathymically in the homozygote individuals carrying this SNP (Kursawe \& Paschke 2007). These findings established an understanding that noncoding SNPs of intron 1 within the TSHR have a geneticepigenetic interaction that adjusts the TSHR expression in thymus and boosts evasion of TSHR-reactive T cells from central tolerance. Additionally, hypermethylation in intron 1 has been identified where various GD-associated polymorphisms are reported (Table 1). The results show the contribution of dysregulated DNA methylation and histone modifications of $\mathrm{T}$ cell signaling genes in patients with GD that affect 'Peripheral/Central Tolerance' (Limbach et al. 2016); however, the key mechanism of TSHR involvement in GD development is elusive.
TPO

TPO, a thyrocyte apical plasma glycosylated membranebound enzyme, involves in producing the thyroid hormones T3 and T4 by iodine oxidation/iodination of tyrosyl residues of the Tg molecules (Kopp et al. 2017) (Fig. 1A). As a marker of AITD, over 90\% of GD patients show an increased amount of anti-TPO autoantibodies (Silva et al. 2003). The TPO gene is merely expressed in thyroid glands, while is imperative for proper functions of at least three thyroid-specific transcription factors, including NKX2-1, FOXE1, and PAX-8 (Grasberger et al. 2005). Some genetic variations in TPO are associated with GD; for example, rs11675434 is correlated with the development of Graves' ophthalmopathy (GO), especially in male patients with a late-onset GD (Kuś et al. 2017), while c.2268inst is the most frequently identified mutation in the TPO gene within the Taiwanese 
Table 1 Most significant polymorphisms of TSHR that are associated with GD.

\begin{tabular}{|c|c|c|c|c|c|c|}
\hline Genetic variation & Function & Year & Population & Increased risk & $\begin{array}{l}\text { Associated } \\
\text { region }\end{array}$ & Reference \\
\hline rs2234919 & $\begin{array}{l}\text { Ameliorates G(s)alpha protein } \\
\text { activation of TSHR }\end{array}$ & 1995 & Caucasian & Yes & Exon 1 & (Ban et al. 2002) \\
\hline DS14S81 & NR & 1997 & Caucasian & Yes & Chr. 14q31 & (Tomer et al. 1999) \\
\hline TSHR-AT & NR & 2000 & Japanese & Yes & Intron 2 & (Yin et al. 2008) \\
\hline rs1991517 & $\begin{array}{l}\text { rs1991517 alters the binding } \\
\text { affinity to CAMP, thus changes } \\
\text { signaling pathways mediated } \\
\text { by TSHR }\end{array}$ & 2002 & Russian & Yes & Exon 10 & (Cuddihy et al. 1995) \\
\hline D14S258 & NR & 2003 & Caucasian & Yes & Chr. $14 q$ & (Tomer et al. 2007) \\
\hline rs2239610 & $\begin{array}{l}\text { This polymorphism is associated } \\
\text { with higher serum } \\
\text { concentrations of free thyroxin } \\
\text { and TRAb with unknown } \\
\text { mechanisms }\end{array}$ & 2003 & Chinese & Yes & Intron 1 & (Hiratani et al. 2005) \\
\hline rs2268458 & NR & 2005 & Caucasian & Yes & Intron 1 & (Brand et al. 2009) \\
\hline $\begin{array}{r}\text { rs2268475, } \\
\text { rs3783938 }\end{array}$ & NR & 2005 & Japanese & Yes & $\begin{array}{l}\text { Intron 7, } \\
\text { Intron } 8\end{array}$ & (Tomer et al. 1997) \\
\hline rs3783941 & NR & 2007 & Caucasian & Yes & Intron 8 & (Płoski et al. 2010) \\
\hline rs2268458 & NR & 2008 & Caucasian & Yes & Intron 1 & (Qu et al. 2010) \\
\hline $\begin{array}{l}\text { rs179247, } \\
\text { rs12101255 }\end{array}$ & $\begin{array}{l}\text { Can increase the production of } \\
\text { ST5 and change the TSHR } \\
\text { expression }\end{array}$ & 2009 & Caucasian & Yes & Intron 1 & $\begin{array}{l}\text { (Colobran et al. } \\
\text { 2011) }\end{array}$ \\
\hline rs12101261 & $\begin{array}{l}\text { Decreases the intrathymic TSHR } \\
\text { expression through signaling } \\
\text { pathways mediated by } \\
\text { promyelocytic leukemia zinc } \\
\text { finger (PLZF) protein }\end{array}$ & 2011 & Chinese & Yes & Intron 1 & (Chu et al. 2011) \\
\hline rs12101255 & $\begin{array}{l}\text { By binding to PLZF protein } \\
\text { decreases the intrathymic TSHR } \\
\text { expression }\end{array}$ & 2012 & Chinese & Yes & Intron 1 & (Yin et al. 2012) \\
\hline rs2284720 & NR & 2013 & Caucasian & Yes & Intron 1 & (Tomer et al. 2013) \\
\hline rs179243 & NR & 2014 & Chinese & Yes & Intron 1 & $\begin{array}{l}\text { (Stefan \& Faustino } \\
\text { 2017) }\end{array}$ \\
\hline rs12885526 & NR & 2015 & Brazilian & Yes & Intron 1 & (Bufalo et al. 2015) \\
\hline $\begin{array}{l}\text { rs179247, } \\
\text { rs3783948 }\end{array}$ & NR & 2016 & Italian & Yes & Intron 1 & (Lombardi et al. 2016) \\
\hline $\begin{array}{l}\text { rs12101261, } \\
\text { rs4903964, } \\
\text { rs179247, } \\
\text { rs2284722, } \\
\text { rs17111394 }\end{array}$ & $\begin{array}{l}\text { rs179247 can increase the } \\
\text { production of ST5 and change } \\
\text { the TSHR expression, while } \\
\text { rs12101261 changes TSHR gene } \\
\text { expression through binding to } \\
\text { PLZF protein. }\end{array}$ & 2016 & Chinese & Yes & Intron 1 & (Jing et al. 2016) \\
\hline $\begin{array}{l}\text { rs4411444, } \\
\text { rs4903961 }\end{array}$ & NR & 2017 & Japanese & Yes & Intron 1 & (Fujii et al. 2017) \\
\hline
\end{tabular}

population (Huang \& Jap 2015). It seems that these kinds of mutations can change TPO protein activity, its expression in serum, or even the serum levels of TPOAb, confirmed by a study introducing nonsynonymous substitutions in TPO (including p.Ala373Ser, p.Ser398Thr, and p.Thr725Pro) in Bangladeshi patients (Begum et al. 2019). However, the molecular mechanisms behind the association between these variants and GD are not clearly understood.

\section{TG gene}

The thyroid gland produces TG playing a pivotal role in both the immune system and thyroid hormone synthesis; the $T G$ gene is also a crucial candidate for GD (Yamashita et al. 1989). TG variants are common and likely contribute to the pathogenesis of autoimmune thyroid diseases (Tomer 2014). Anti-TG antibodies are found in 1 in 10 healthy individuals that cause falsely 


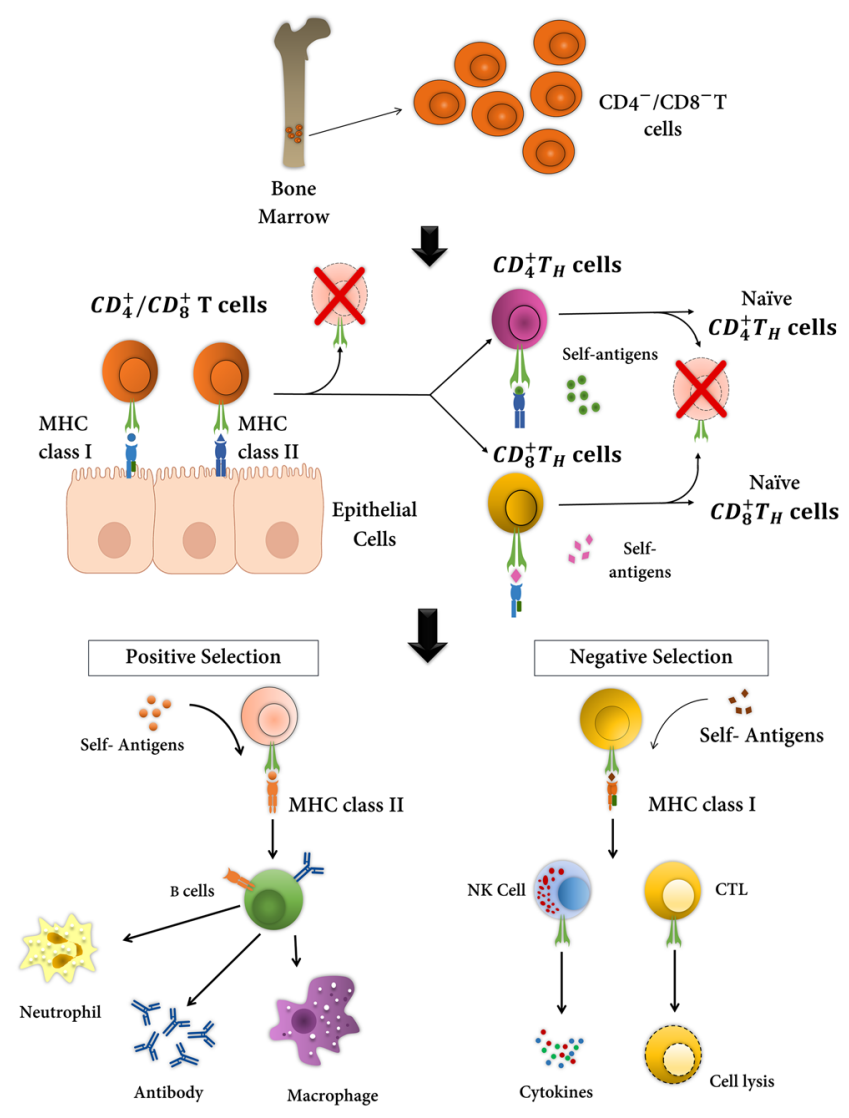

Figure 2

The role of cells and molecules encoded by GD associated genes in T cell and other immune cells during central tolerance and immune responserelated pathways. Progenitor T cells are generated in the bone marrow. The positive and negative selections in the thymus are required to deplete the nonfunctional and autoreactive T cells. During positive selection, antigen-presenting HLA molecules bind to immature T cells and provide a survival signal to T cells. During negative selection, autoreactive $\mathrm{T}$ cells are recognized by binding to self-antigens. These T cells are distinguished as autoreactive T cells and undergo apoptosis. Externally derived proteins are obtained by the antigen-presenting cells (APCS), converted to antigens, bound to MHC class II molecules, and presented on the APC surface to be recognized by $C D 4^{+} \mathrm{T}$ cells. If antigens are recognized as foreign antigens, $B$ cells will be activated followed by antibodies secretion, and macrophages and neutrophils recruiting by cytokines' CD4+ T cells. Internally derived antigens bound to HLA class I molecules and presented on the cell surface for recognition by CD8+ T cells. If the antigen is detected as a foreign antigen, the cell destruction is carried out by cytotoxic T cells and NK cells. The GD associated variants to this pathway have been reported in CTLA4, PTPN22, and IL2RA. The figure is depicted according to the data from Kyewski \& Klein (2006) and Nemazee (2017). A full color version of this figure is available at https:// doi.org/10.1530/JME-20-0078.

low or rarely high levels of reported TG. These antibodies are often detected in patients with AITDs, especially GD (Antonelli et al. 2014), and also in conditions such as Hashimoto's encephalopathy, papillary or follicular thyroid carcinoma, systemic lupus erythematosus (SLE), and type 1 diabetes (T1D) (Wallace \& Stone 2003).
Further reports demonstrated amino acid substitutions in TG (SNP cluster of exon 10-12 and an exon 33) raise the susceptibility to AITDs (Ban et al. 2003). Indeed, the exon 33 SNPs demonstrate adequate evidence of interaction between TG and HLA-DR3 that can lead to elevating GD susceptibility (Ban et al. 2003).

As an SNP in the promoter region of the $T G$ gene, rs180195 has been identified to increase susceptibility to AITD by an interferon $\alpha$-modulated mechanism (Stefan et al. 2011). This SNP has an epigenetically-important interaction with interferon regulatory factor 1 (IRF-1) to develop GD (Tomer 2014). Stefan et al. detected that $-1623 \mathrm{~A} / \mathrm{G}$ SNP modifies the binding site for IRF-1, in fact, the disease-associated allele $(G)$ limited the increase of $T G$ promoter activity through IRF-1 binding (Stefan et al. 2011). Therefore, a novel mechanism incorporating both epigenetically-important interaction (IFn- $\alpha$ ) and genetic factors $(T G)$ can be implicated in GD development.

\section{T cell response regulatory genes}

Various proteins have been described to play important roles in T cell differentiation, maturation, and activation. In the following, we list some of the well-established genes and summarize their possible roles in GD development.

\section{Major histocompatibility complex}

Major histocompatibility complex (MHC), also known as Human Leukocyte Antigen (HLA) in humans, are encoded proteins on the cell surface that are essential for the acquired immune system to recognize antigens. There are three major subgroups of HLAs playing roles in antigen presentation, autoimmune reactions, and tissue allorecognition (Simpson 1988). A strong correlation between the HLA class I and class II regions with GD has been identified (Wellcome Trust Case Control Consortium, Australo-Anglo-American Spondylitis Consortium (TASC) et al. 2007, Zeitlin et al. 2008), that is, HLA class I allele HLA-B8 and HLA class II alleles are strongly associated with GD risk (Chen et al. 2000).

An interaction of $T G$ SNPs in exon 33 has been identified that can synergistically facilitate the interaction of HLA-DR $\beta 1-\operatorname{Arg} 74$ with TG genotype as a diseaseassociated genotype of Trp1980Arg SNP (Simmonds et al. 2005). An arginine at $\beta 74$ is encoded by $H L A-D R B 1^{*} 03$, while $H L A-D R B 1{ }^{*} 07$, as a member of a protective DR7 haplotype, encodes glutamine at the same location (Simmonds et al. 2005). Moreover, a statistical interaction has been observed between such amino acid variants in 
$T G$ and HLA-DR $\beta 1$-Arg74 leading to higher susceptibility to GD (Hodge et al. 2006) and other autoimmune diseases (Menconi et al. 2010, Bernecker et al. 2012). Li et al. showed that TSHR peptides that bind to the HLA-DRß1-Arg74 with high affinity represent key pathogenic TSHR peptides triggering GD and that blocking their presentation to CD4 ${ }^{+}$T-cells can be used as a novel therapeutic approach in GD (Li et al. 2020a).

DQB1* alleles and the amino acid residues have been shown to contribute to AITD in South Indian populations. In fact, DQB1*02:02, *06:03, *06:09, ${ }^{*} 03: 02$, and ${ }^{*} 03: 03$ alleles show a higher risk, while ${ }^{*} 02: 01,{ }^{*} 05: 02$, and *06:02 alleles can be deemed as a protecting factor toward AITD (Ramgopal et al. 2018). Similarly, investigations on populations of African descent showed a high association of DRB3 ${ }^{*} 01: 01$ in Jamaicans (Smikle et al. 2001) and an association of DRB3*02:02 and DQA1*05:01 in AfricanAmericans (Chen et al. 2000). In these studies, only DRB1*05:31 and DRB1*14:03 could raise the GD risk. Although various studies show HLA interactions and their associations with GD, the distinct mechanisms have remained unclear. However, it seems that HLA haplotypes exert their functions through an epistatic mechanism affecting the regulation of the intensity of GD by T-cells. Such T-cells recognize a protective HLA motif on antigenpresenting cell (APCs) surfaces, for example, DRB1*13:02, or interfere with anti-TSHR production (interfere with thyroid hormone synthesis) (Sasazuki et al. 2016).

\section{CD40}

As a member of the tumor necrosis factor (TNF) superfamily, $C D 40$ is expressed on a wide range of immune cells, such as B-cells, macrophages, and dendritic cells. Furthermore, CD40 ligand (CD40L), also known as CD154 that binds to the CD40 receptor is predominantly expressed by activated $\mathrm{CD}^{+} \mathrm{T}$ cells (Fig. 3A). The interaction of CD40-CD154 is vital for more activation of humoral immunity through triggering B-cells (Ferrari et al. 2001) that is supposed to trigger hyperthyroidism. Several groups have aimed to show the role of CD40 in GD, for example, Iscalimab is an antibody that has been assessed in various autoimmune conditions (e.g. RA and GD) because of its ability to prevent the CD40-CD154 interaction (Genere \& Stan 2019), increasing hopes to treat GD patients.

Several studies have established $C D 40$ expression in the thyroid follicular cells in GD patients in which CD40 was associated with uncontrolled HLA class II expression and ICAM1 overexpression (Bottazzo et al. 1983, Tolosa et al.
1992). Thus, it is hypothesized that thyroid follicular cells could act as APCs under special circumstances (Jacobson et al. 2007), so affecting T cells production/regulation.

CD40 rs1883832 $(-1 \mathrm{~T}>\mathrm{C})$ in the Kozak sequence is associated with GD (Hiromatsu et al. 2005), confirmed by a meta-analysis in other populations (Houston et al. 2004, Kurylowicz et al. 2005, Wang et al. 2019). It appears that the $\mathrm{C}$ allele of rs1883832 provokes a proinflammatory endothelial cell phenotype, compensated by enhanced CD40 shedding to neutralize excess CD40 ligand (Sultan et al. 2020). Besides, high concentrations of soluble CD40L has been identified in children with newly diagnosed GD and a correlation between soluble CD40L and both TSHR antibodies and thyroid volume, which may indicate a biologically active role for soluble CD40L in the pathogenesis of GD (Metwalley et al. 2020). However, there is little information showing how CD40 contributes to GD pathogenesis.

\section{Interleukins}

Interleukins (ILs) can significantly participate in inflammation, cell differentiation, and immune responses, and thus play essential roles in various immunological diseases (Sabzevary-Ghahfarokhi et al. 2018). Previously, we confirmed that different polymorphisms in proinflammatory cytokines can contribute to GD susceptibility in Iranian patients. We also demonstrated a remarkable correlation between GD and IL-2-330G, IL-12-1188C, and IFNG UTR 5644T alleles (Anvari et al. 2010). Other studies showed the correlation between ILs and GD; for example, a considerable positive association between polymorphisms of IL1A and IL-1RA genes and predisposition to GD have been demonstrated (Khalilzadeh et al. 2009); although, it was reported earlier by Cuddihy et al. that none of the A2 alleles of the $I L-1$ receptor antagonist gene and the $I L 1 A$ exon 5 polymorphism allowed for increased susceptibility to GD (Cuddihy \& Bahn 1996). This significant difference can be justified by the founder effect, sample size, and technical issues in immunogenetic tests.

It seems that IL-6 plays a substantial role in GD, for example, a considerable association of IL6-174 G/C polymorphism and also the increased risk of GD in dominant, recessive, and homozygote contrast models have been reported and confirmed by some meta-analysis data (Imani et al. 2017). Moreover, it has been demonstrated that rs1800795 of IL-6 can increase susceptibility for GD (Tu et al. 2017). These data have been verified on the protein level as well, for example, augmentation of IL-6 
A

redisposing Genetic factors: CTLA-4, HLAs, etc.

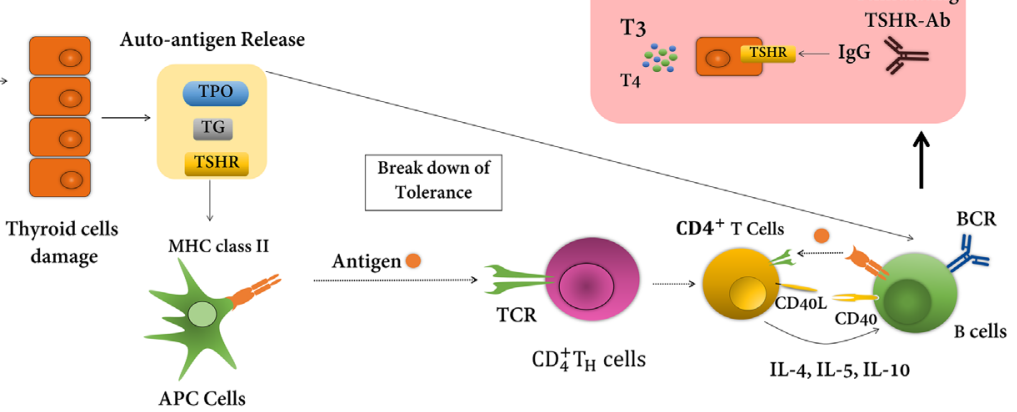

B-cell Signaling Pathway

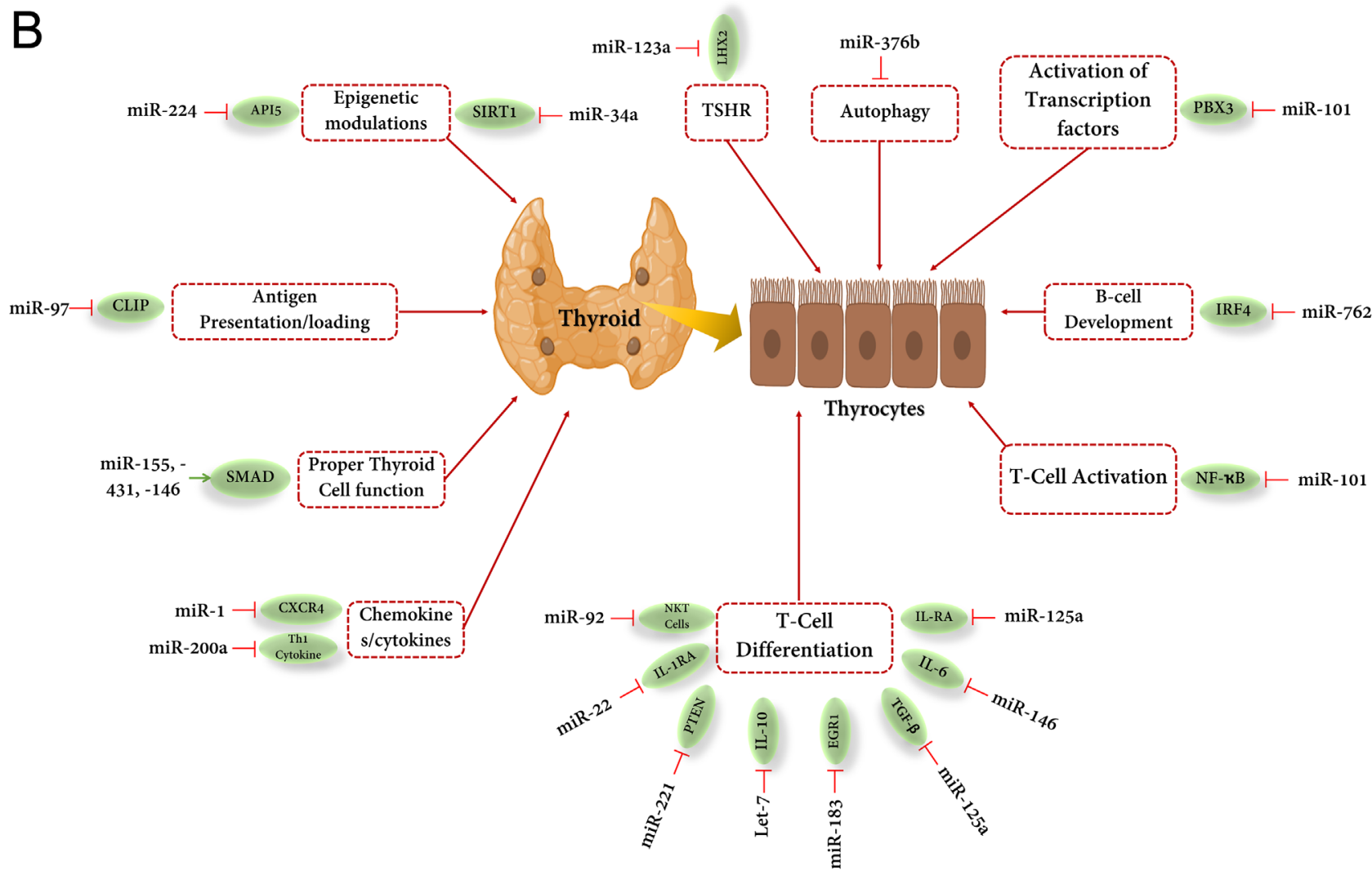

Figure 3

(A) A possible mechanism that involves TPO, CD40, HLA Class II, TG, and TSHR in GD. GD can be characterized by the presence of thyroid autoantibodies against TPO and TG in serum and thus, various degrees of thyroid dysfunction are expected. During GD, environmental factors along with genetic susceptible loci make a situation in which thyroid cells will be damaged and TSHR will be recognized as the most critical autoantigen. After breaking down the tolerance, aberrant production of stimulating TSHR antibodies exacerbate the condition and pave the way to hyperthyroidism. Antibodies mimic the effects of the hormone on thyroid cells, TSH, stimulating autonomous production of thyroxine (T3), and triiodothyronine (T4), so causing

hyperthyroidism. Figure A is redrawn from Ramos-Leví \& Marazuela (2016). (B) Most important miRNAs contributing to GD. These miRNAs can be used as a diagnosis/prognosis biomarker of GD patients. A full color version of this figure is available at https://doi.org/10.1530/JME-20-0078.

and IL-6R expression in sera of 49 GD patients (Salvi et al. 1996) have been reported.

IL-17 expression is significantly correlated with thyroid-associated ophthalmopathy pathogenesis and development (Chen 2019). IL-17 can play dual functions in GD: a predisposing or protecting factor; for example, the portion of $I L-17 F /$ rs763780 genotypes in GD patients varied considerably from the control groups; the frequency of A allele of rs3819025 was lower in GD patients. These data show that $I L-17 F /$ rs763780 polymorphism can increase predisposition to GD with unknown molecular mechanisms. On the other hand, IL-17A/ 
rs3819025 SNP has been identified as a likely protective allele of GD in Chinese populations (Yan et al. 2012).

The genetic association of $I L-16$ and $I L-23 R$ has been also identified. The interactions of IL-16 recruit T helper cells in GD. Gu et al. showed an association of rs4778889, rs1131445, and rs4778641 of IL-16 with an increased risk of GD in the Chinese population (Gu et al. 2008). Variants in the $I L-23 R$ gene, namely A, C, and T alleles of rs2201841, increase the susceptibility of GD by changing the expression and/or function of IL-23R, thereby triggering a pro-inflammatory signaling cascade (Huber et al. 2008).

Some studies suggested that interleukins might be used as a diagnostic marker for GD. For instance, IL1B gene promoter $(-511 \mathrm{C} / \mathrm{T})$ polymorphism may be used to predict GD susceptibility (Chen et al. 2005). Similarly, Yao et al. suggested that IL-32 and IL-32 $\alpha^{+}$cells may be associated with the pathogenesis of GD and also introduced IL-32 as a promising target and a marker for, respectively, treatment and diagnosis of GD (Yao et al. 2019a).

In some cases, the conclusion about the involvement of IL polymorphism in GD is controversial; for instance, there is an association between a promoter polymorphism of the $I L-4$ gene and GD although Heward et al. showed that this polymorphism does not confer protection against the GD development in Caucasians in the United Kingdom (Heward et al. 2001). Furthermore, polymorphisms of the $I L-13$ gene could confer susceptibility of Japanese populations to $\mathrm{GD}$, that is, a decrease of allele frequency of $2044 \mathrm{~A}$ in exon 4 and $-1112 \mathrm{~T}$ in GD patients was shown (Hiromatsu et al. 2005); however, another study suggested that these polymorphisms do not show any genetic susceptibility to GD at all (Bednarczuk et al. 2003). To some extent, this can be justified by genetic diversity and population structures that are unique for each population. These are the most important limitations in such studies. In sum, this is conclusive that ILs can predispose to GD through aberrant inflammatory signaling cascades.

\section{CTLA4}

Cytotoxic T-lymphocyte-associated protein 4 (CTLA4), also known as $\mathrm{CD} 152$, is a protein receptor involved in immune checkpoint and immune repression responses. Transmembrane protein CD152 quenches $\mathrm{T}$ cell responses and therefore helps to make self-antigen tolerance (Rahman et al. 2019). Several variants in CTLA4 have been reported with increased risk of GD, T1D, RA, and SLE susceptibility (Wang et al. 2014); for example, rs231775 was correlated with a higher risk of GD susceptibility
(Liu \& Zhang 2013). The distinct relationships of CTLA4 polymorphisms with GD and AITDs are still debatable (Ueda et al. 2003); however, it has been proposed that the decreased expression of the soluble form of CD152 (e.g. influenced by rs231775) contributes to GD (Waterhouse et al. 1995, Oaks \& Hallett 2000).

Regulation of $\mathrm{CD}^{+} \mathrm{T}$ cell-related memory responses by CTLA4 may also play a role in developing autoimmune diseases (Devarajan 2014) (Fig. 3A). Indeed, activating heterozygote mutations in CTLA4 increased the rate of autoimmunity, while treating with anti-CTLA4 monoclonal antibodies suppressed $\mathrm{T}$ cell activation and reduced the incidence of AITDs (Torino et al. 2013). It seems that the polymorphisms/genetic variations in the CTLA4 can affect gene expression. Hence, low concentrations of intracellular CTLA4 may be associated with low cell surface expression of CTLA4 and therefore with reduced negative control of $\mathrm{T}$ cell proliferation, ultimately leading to $\mathrm{T}$ cell hyperresponsiveness and predisposition to GD.

\section{PTPN22}

PTPN22 encodes human lymphoid tyrosine phosphatase and shows a significant association with autoimmune diseases including GD, RA, SLE, and T1D (Stanford \& Bottini 2014, Zhang et al. 2018). The interaction of lymphoid tyrosine phosphatase with the Csk and Fyn kinases functions as negative regulators of $\mathrm{T}$ cell receptor signaling, such as pattern recognition receptors (PRR), type 1 IFN pathway signaling, and IFn- $\gamma$-dependent activation (reviewed in Bottini \& Peterson 2014).

There are some genetic variations in PTPN22 showing a great association with GD; for example, rs2476601 that is associated with T1D, RA, SLE, and GD (Vang et al. 2005) is in the C-terminal of the protein presumably affects the interaction of this domain with adaptor TRAF3 and Csk kinase and results in PRR signaling reduction despite TCR signaling enhancement (Bottini \& Peterson 2014). PRRs are categorized based on the recognition of ligands from two distinct groups: Pathogen-Associated Molecular Patterns and Damage-Associated Molecular Patterns. The contribution of these groups in the etiology of GD has been discussed (reviewed in Kawashima et al. 2013). Although many studies confirmed the association of rs2476601 with GD, one study showed that this polymorphism was not associated with GD in Kashmiri populations (Shehjar et al. 2018). The SNP might be linked with a higher risk of GD within the adult north-eastern Polish population (Wawrusiewicz-Kurylonek et al. 2019) 
and occasionally affected the GD onset in the Chinese Han population (Li-qun et al. 2010). Autoimmune PTPN22 rs2476601 risk allele A controls the frequency of regulatory $\mathrm{T}$ cells in human peripheral blood that is decreased in GD (Valta et al. 2020). Other genetic variations in this gene also show the association with GD although there is not enough information about underlying molecular mechanisms.

\section{FCRL3}

Fc receptor-like protein 3 (FCRL3) protein involves immunoreceptor tyrosine-based activation motifs (ITAMs) and may act as an activator of the immune system. Different studies confirmed the association of FCRL3 promoter SNPs with RA, AITDs, and SLE (Kochi et al. 2005), for example, three polymorphisms as in FCRL3_3C, FCRL3_5C, and FCRL3_6A were associated with multiple sclerosis (MS) and also were remarkably tied with a higher risk of GD in the Chinese Han population (Yuan et al. 2016). Additionally, several meta-analyses showed that the impressions of these novel variants on GD predisposition are different between Asian and Caucasian populations (Fang et al. 2016).

A/G SNP at position -169 in the promoter region of the FCRL3 is strongly correlated with the predisposition of GD among the Chinese population. This allele is tightly pertinent to positive TSHR autoantibodies that in turn result in thyroid diseases (Jin et al. 2015). It seems that the genetic variations can exert their effects through changing the gene expression; for example, Stefanic et al. confirmed increased mRNA levels of FCRL3 in peripheral blood T cells from end-stage, long-standing, and/or more aggressive autoimmune thyroid diseases were related to disease severity (Štefanić et al. 2019). This study acknowledges that co-inhibitory receptors, for example, FCRL3 and T cell immunoglobulin and ITIM domain, play an essential role in AITDs though their primary roles are uncertain.

\section{Other important genes in the immune system}

Several gene abnormalities may promote GD susceptibility. For example, it has been acknowledged that the $B A C H 2$ is critical for class switch recombination and somatic hypermutation (Muto et al. 2004) and is an essential regulator of $\mathrm{CD}^{+}$T-cell differentiation and hinders inflammatory disease by keeping a balance between tolerance and immunity (Roychoudhuri et al. 2013). A significant association of $B A C H 2$ rs9344996 with GD was reported, which can be clarified by its linkage to $\mathrm{BACH} 2$ rs2474619 in diverse populations (Liu et al. 2014). The genetic variants in the $B A C H 2$ are associated with different autoimmune diseases such as asthma, coeliac disease, vitiligo, MS, and T1D (Cooper et al. 2008, Dubois et al. 2010, Sawcer et al. 2011, Jin et al. 2012). It was also shown that rs3757247 can increase the risk of autoimmune Addison's disease in humans (Pazderska et al. 2016). Despite these studies, the exact molecular mechanism by which BACH2 polymorphisms increase the risk of AITD needs further studies.

A genome-wide association study (GWAS) with $>500,000$ SNPs detected a new susceptible region located in 6q27 loci (Ribonuclease T2 (RNASET2)-FGFR1 oncogene partner FGFR1OP-CCR6) and also an intergenic region at 4p14 (GDCG4p14) (Ban et al. 2013). RNASET2 rs9355610 was associated with the susceptibility to GD in the Chinese Han population (Chen et al. 2015) and shown in other populations (Ban et al. 2013). Moreover, the G allele of rs9355610 may be a protective factor for liver damage in patients with GD, suggesting that RNase T2 has a potential intervention effect on GD and liver damage. This can per se provide a new target for the diagnosis and targeted therapy of GD combined with liver damage (Zhang et al. 2018).

Forkhead box P3 (FOXP3), also is known as Scurfin, is involved in immune system responses and may have a role in the etiopathogenesis of AITDs. FOXP3 is a master regulator in proper $\mathrm{T}$ cell development and also functions of Tregs. In the Chinese Han population, four SNPs including $-2383,-3279,-3499$ in the promoter region and IVS9+459 in the intron were genotyped and it was shown that these polymorphisms were highly tied with GD susceptibility (Zheng et al. 2015). Li et al. found that rs3761548 and rs3761549 polymorphisms in Foxp3 were associated with a higher risk of GD among Asians, possibly because of the suppressed function of regulatory $\mathrm{T}$ cells and extended autoimmune responses (Li et al. 2020b).

PRICKLE1 protein can negatively regulate the Wnt/ beta-catenin signaling pathway. Wnt signaling is vital for dendritic cells to appropriately regulate immunity and tolerance (Swafford \& Manicassamy 2015). An association between PRICKLE1 rs4768412 and GD was reported using an immunochip study (Consortium et al. 2012) that led to this notion that rs4768412 was nominally more frequent in pediatric-onset GD than adult-onset GD patients, which might be linked to the age of GD onset (Kus et al. 2019).

The elevated concentration of B lymphocyte activating factor (BAFF) that is vital for B cell-survival, -activation, and -differentiation has been also found in GD patients. In fact, various genetic variants within the $B A F F$ gene can change the BAFF expression in GD 
patients (Kuo et al. 2008), confirmed by a study showed that the expression of $B A F F$ and its particular receptor (BAFF-R) was elevated in infiltrating lymphocytes in GD-derived thyroid tissue (Campi et al. 2015). Similarly, the association of rs9514828 and rs4000607 in UK patients with GD have been reported that can change the gene expression (Lane et al. 2019). As an underlying molecular mechanism, Wang et al. showed that the skewed expression profile of BAFF receptors on B lymphocytes may mediate autoimmunity in GD, suggesting that restoring the normal expression profile can be a new strategy for GD treatment (Wang et al. 2020). In other words, blocking the interaction of BAFF with its receptor negatively affects B-cell proliferation, indirectly decreasing B-cell survival and reducing the production of autoantibodies in GD (Lane et al. 2020).

Lastly, the SCGB3A2 gene, which encodes uteroglobin-related protein 1 , plays important role in inflammation and immunologic responses (Yoneda et al. 2016). SCGB3A2 -112G $>$ A promoter polymorphism has been reported in association with GD in the Chinese population (Xue et al. 2014). This polymorphism was investigated in Caucasian cohorts, proposing this polymorphism can be noticed as a potential marker linking susceptibility to allergy/asthma and GD (Chistiakov et al. 2011). The main function of SCGB3A2 in GD remains elusive. The most important genetic factors contributing to GD are summarized in Table 2.

\section{How epigenetic factors contribute to GD}

Epigenetic modulations have been suggested to influence susceptibility to AITD. Environmental factors such as stress, iodine diet, infections, and smoking can regulate and alter DNA methylation and histone modifications (Tomer \& Huber 2009). These alternations along with gene silencing triggered by non-coding RNAs are the main epigenetic mechanisms that contribute to $\mathrm{T}$ cell differentiation and activity (Cai et al. 2015). The epigenetic mechanisms, indeed, regulate the chromatin structure and switch genes from 'on' to 'off', reversibly and temporarily. In the following, we summarized the important epigenetic mechanisms identified in GD.

\section{DNA methylation}

DNA methylation is a process in which methyl groups are added to target DNA, mediated by DNA methyltransferases (DNMTs). DNA methylation can silence gene expression by the addition of a methyl group to cytosine in CpGs, which recruits methylCpG-binding domain proteins that, in turn, are a starting signal for other modulators altering chromatin remodeling and transcriptional repression (reviewed in Coppedè 2017). Similar to many autoimmune diseases, GD is more common in females than men, a process that can be justified by skewed $\mathrm{X}$ chromosome inactivation (XCI) in women, that is, inactivation of either the maternal or paternal X chromosome. Various important immune-related genes are located in the $\mathrm{X}$ chromosome (e.g. CD4OL, FOXP3, and toll-like receptor 7) that can be silenced in the XCI process. The fact is that the skewed XCI is associated with clinically overt AITD, particularly GD (Simmonds et al. 2014), and it has been also suggested that XCI is related to the AITD prognosis, not to its development (Coppedè 2017).

Different polymorphisms have been investigated in DNA methylation genes that can affect GD susceptibility. For example, rs2228612 in DNMT1 was reported in association with DNA hypomethylation and with the intractability of GD (Arakawa et al. 2012). On the other hand, rs1801133 in methylenetetrahydrofolate reductase (imperative for a chemical reaction involving the vitamin folate as the early substrate of methylation) was associated with reduced GD risk in women (Mao et al. 2010).

Genome-wide DNA methylation studies in GD have exhibited DNA methylation profiles in new CpG sites, among them many genes and pathways are related to IFN signaling, immune responses, lymphocyte activation, and HLA loci. The results indicate that GD patients have many hypomethylated CpGs sites in their CD8+ T cells. For instance, hypomethylation of the NOTCH1 gene that regulates $\mathrm{T}$ cell differentiation has been found in AITD (Yui \& Rothenberg 2014, Limbach et al. 2016). Limbach et al. identified a preferable differential methylation cluster at the MHC region on the $6 \mathrm{p} 22.1$ to $6 \mathrm{p} 21.3$ and methylation distinguished peaks at the HLA class I locus (HLA-A, HLA-B, HLA-E, and TRIM39). They identified alternations in methylation marks at HLA class II (HLA-DRB1, HLA-DMB, PSMB8, and TAP1) and class III (TNFA and LTA) genes. Approximately $40 \%$ of the CpGs undergone hypo/hypermethylation are located within intragenic regions, and less than 30\% are in 5 ' regions. Gene expression analysis detected 46 and 980 differentially expressed genes in $\mathrm{CD}^{+}$and $\mathrm{CD}^{+} \mathrm{T}$ cells, respectively; for example, hypomethylation was observed at the $C D 3 E$ gene in $\mathrm{CD}^{+}$and $\mathrm{CD}^{+} \mathrm{T}$ cells. Moreover, several genes were detected in $\mathrm{CD}^{+} \mathrm{T}$ cells of GD patients that had different methylation profiles 


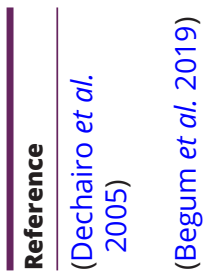
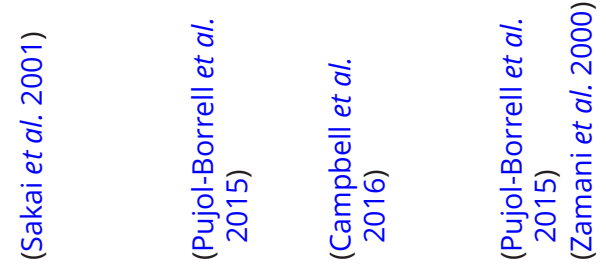

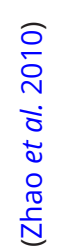

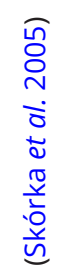

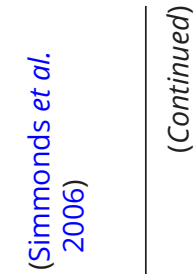

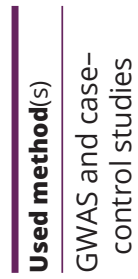

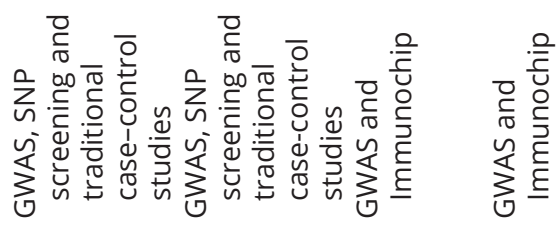

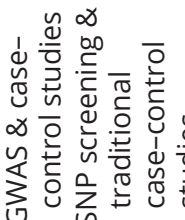

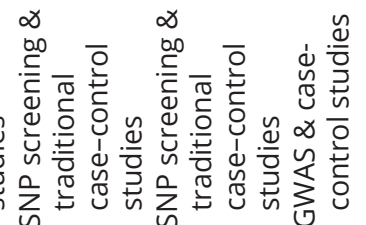

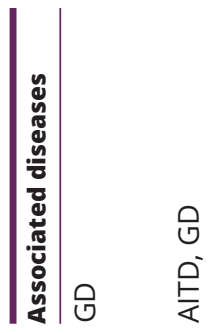

仓

$\frac{\log }{4}$

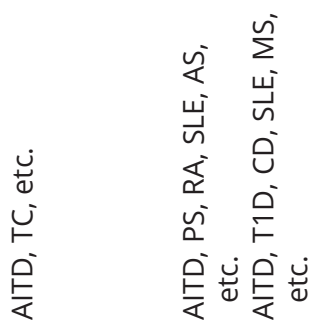

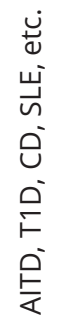

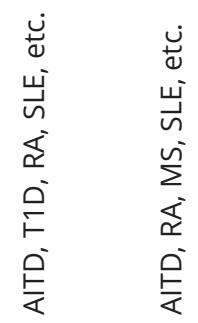
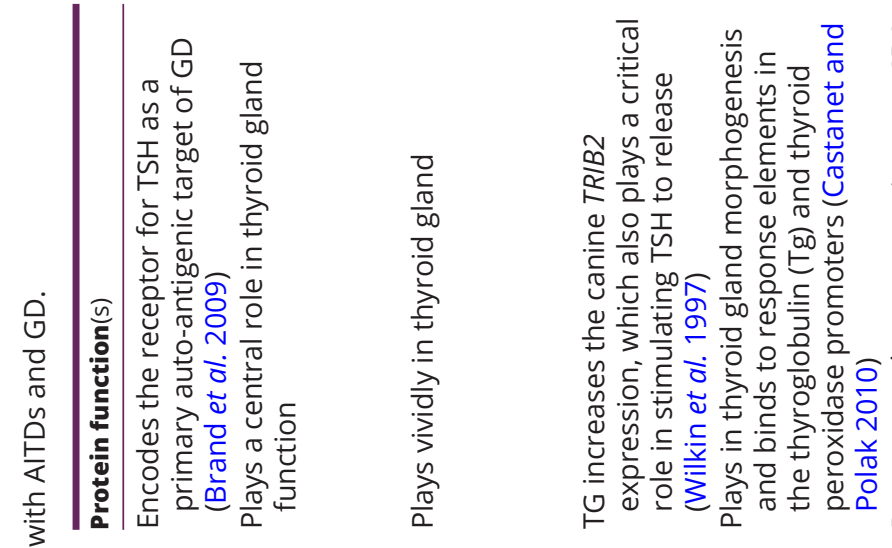

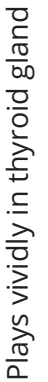
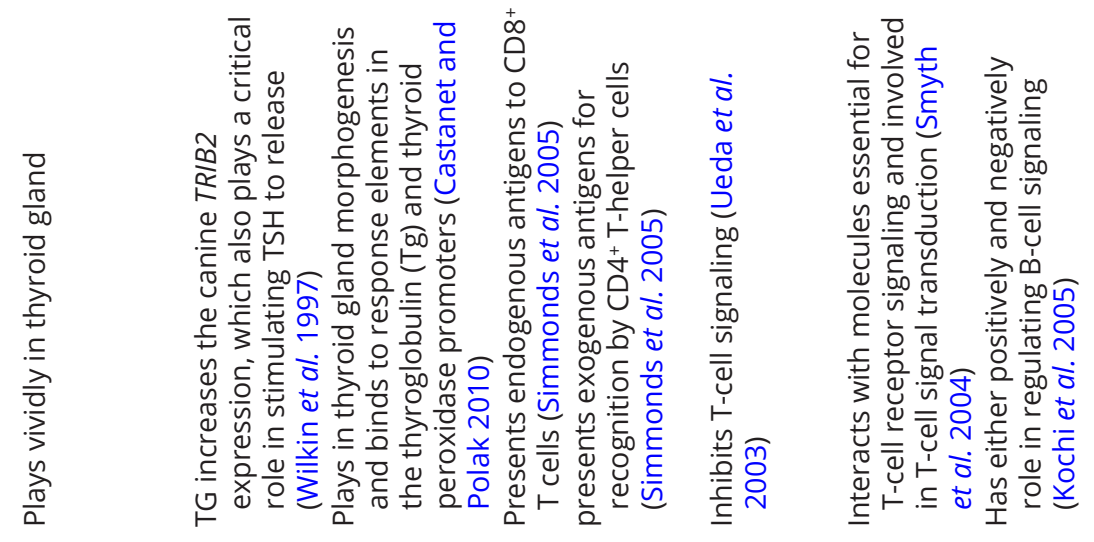

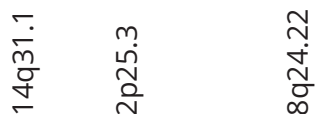

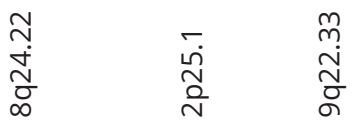

$\overline{\text { กิ }}$

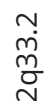

$\stackrel{m}{\frac{m}{2}} \stackrel{\check{m}}{\stackrel{0}{\sigma}}$

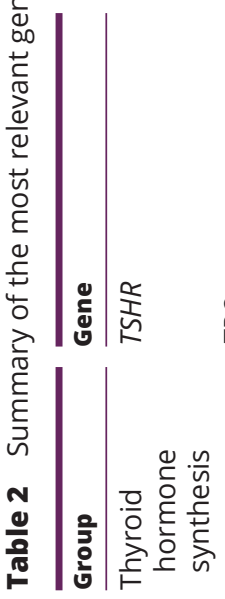

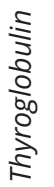

$\stackrel{\frac{0}{k}}{\frac{\pi}{2}}$

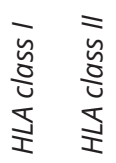

点

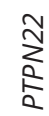

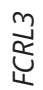

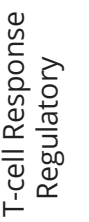




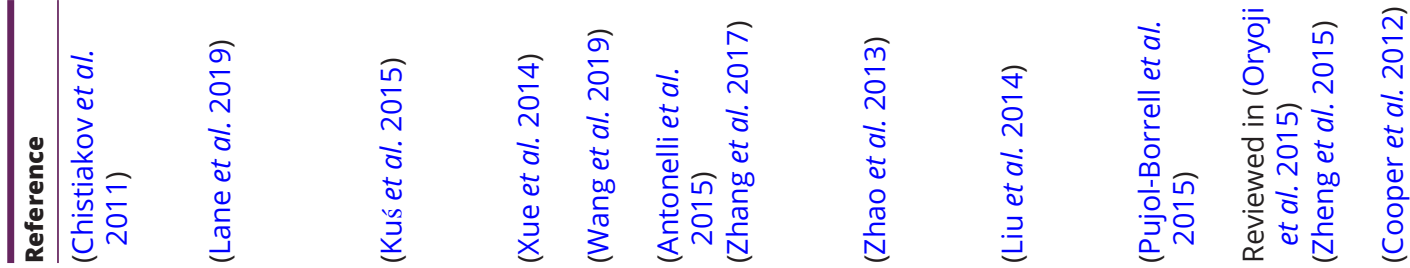
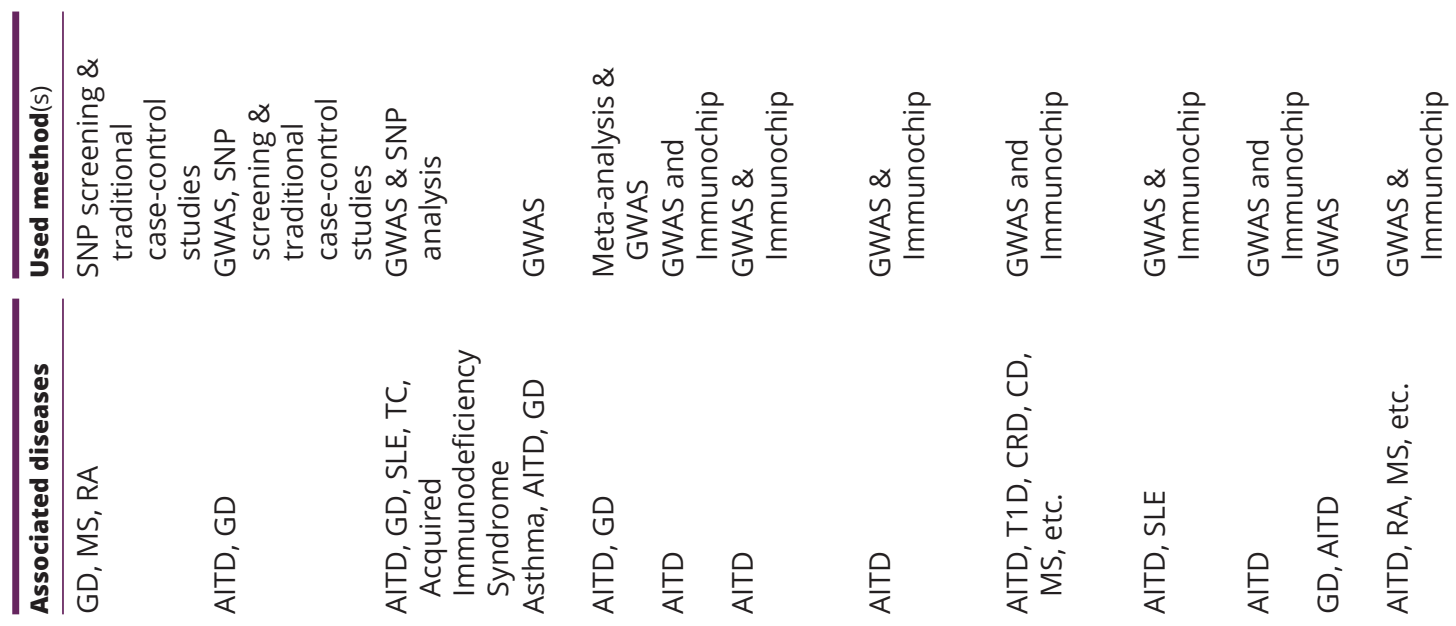

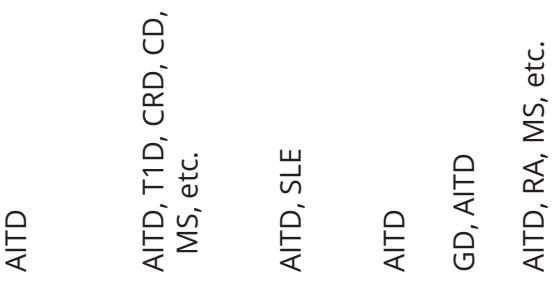
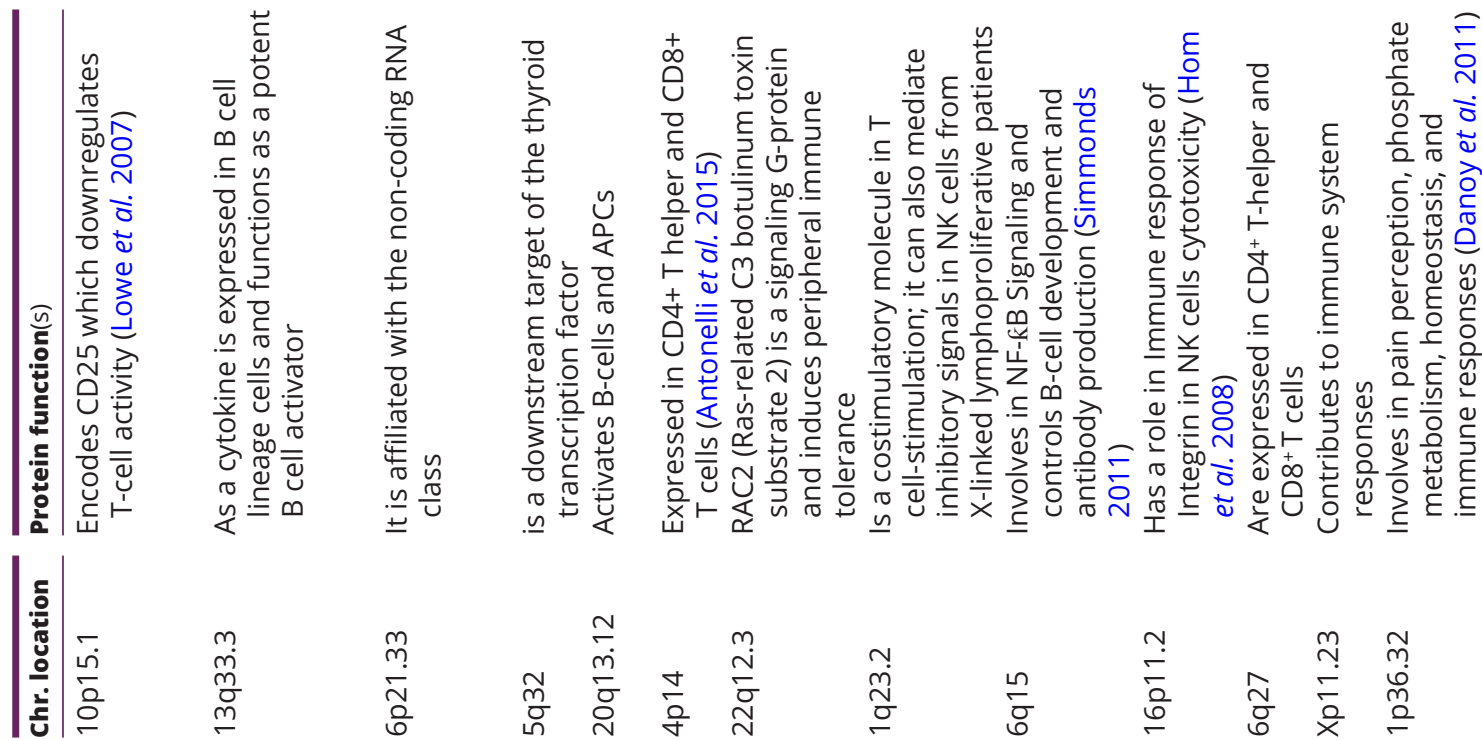

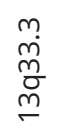

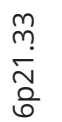

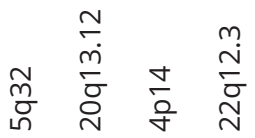

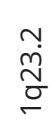

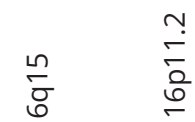

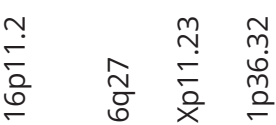

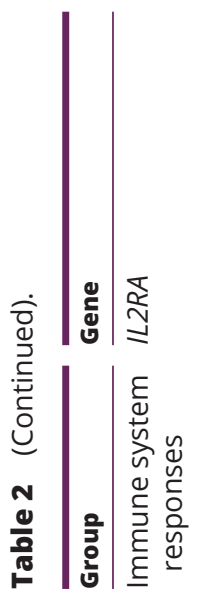



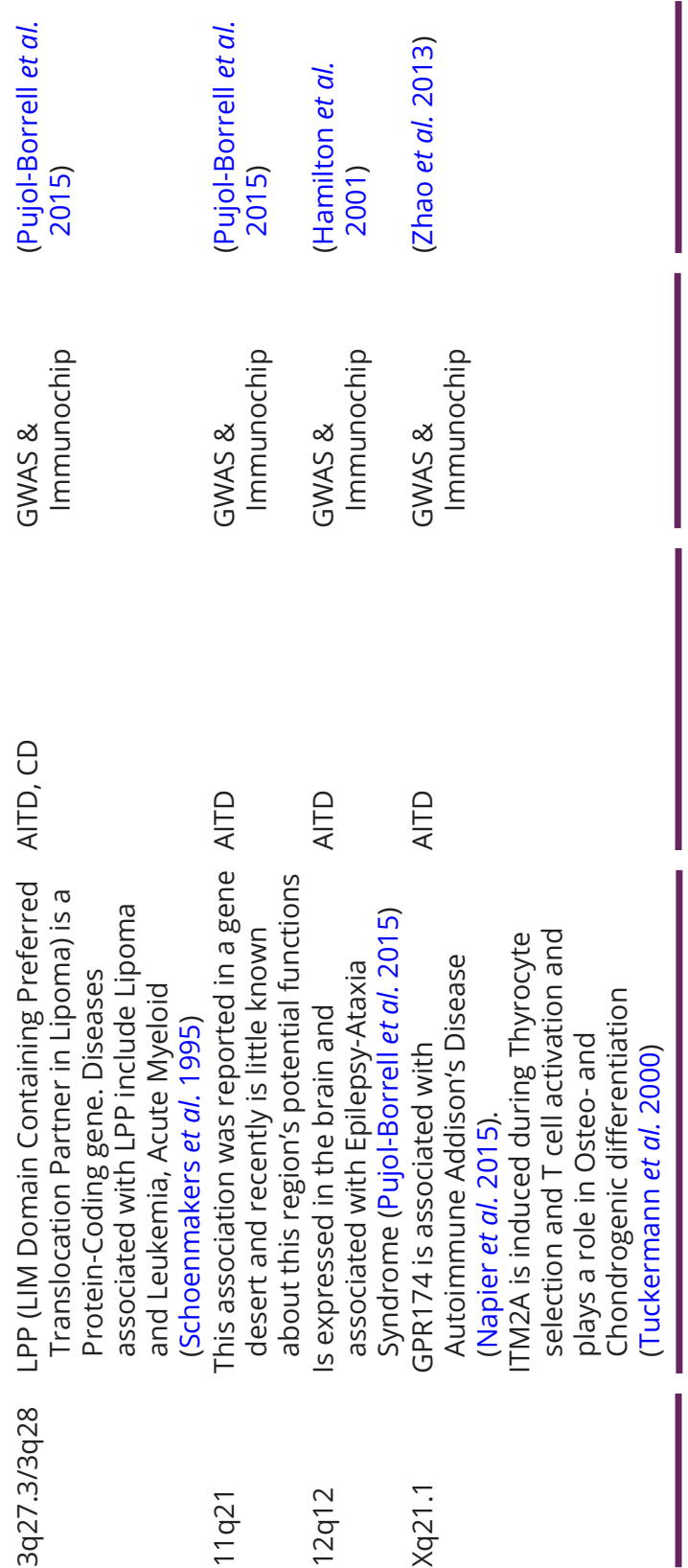

$\vdots$
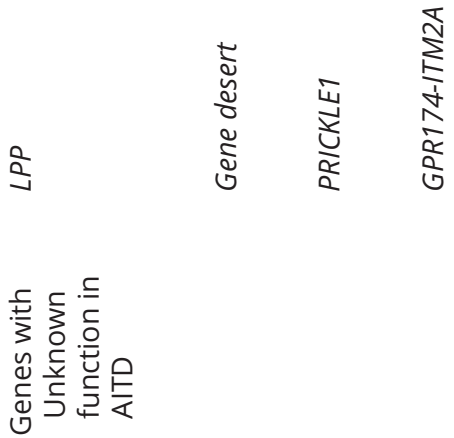

including BCL11B, CXCR4, HLA class I, FYB, TNFRSF1B, IFNG genes (Deng et al. 2019).

\section{Histone modifications}

Various histone modifications have been postulated to either open or condense chromatin structure and can, in turn, change gene expression. These alterations include histone tail acetylation, methylation, phosphorylation, ubiquitination, and sumoylation. Among these, acetylation and methylation have been studied very well, but little in GD. A reduced global histone $\mathrm{H} 4$ acetylation (required for chromatin decompaction) levels with increased levels of histone deacetylase proteins have been reported in peripheral blood mononuclear cells in GD patients (Yan et al. 2015).

Methylation can occur in histone levels as well. For instance, it has been reported that histone methylation is aberrant in peripheral blood mononuclear cells of GD patients (Yan et al. 2019). This process can be attributed to the deregulation of epigenetic modifier genes, suggesting that abnormal histone methylation modification may be involved in the pathogenesis of GD, for example, the hypermethylation of CD3 gene family members, the first intron of TSHR, CTLA4, and B3GNT2 (regulates lymphocyte activation) has been found (Coppedè 2017). On the other hand, the hypomethylation of intercellular adhesion molecule 1 has been reported in association with GD (Cai et al. 2015).

Studies also revealed reduced-trimethylated lysine 4 at histone $\mathrm{H} 3$ (H3K4me3) and acetylation of lysine 27 at histone (H3K27ac) marks at genes that are involved in $\mathrm{T}$ cell activation. To date, plenty of genes have been identified that play role in T cell signaling and activation, for example, CD247, CD3D, CD3E, CD3G, CD8A, LCK, ZAP70, and CTLA4; the common feature of these genes is that they have a low level of H3K4me3 marks in their promoter regions (leading to the decreased gene expression) in both $\mathrm{CD}^{+}{ }^{+}$and $\mathrm{CD} 8^{+} \mathrm{T}$ cells of GD patients. Reduced expression of CD3 gene family members (Limbach et al. 2016) has been also found.

\section{Non-coding RNAs}

A growing body of research shows that non-coding RNAs including microRNAs (miRNAs or miRs) and long noncoding RNAs (lncRNAs) have an impaired expression in AITD. miRNAs are small ( 22 nt), single-stranded, and highly conserved molecules that regulate gene expression via base-pairing with complementary sequences within 
A

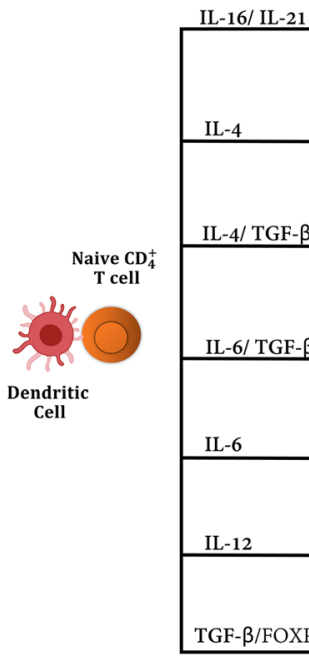

B

\section{Figure 4}

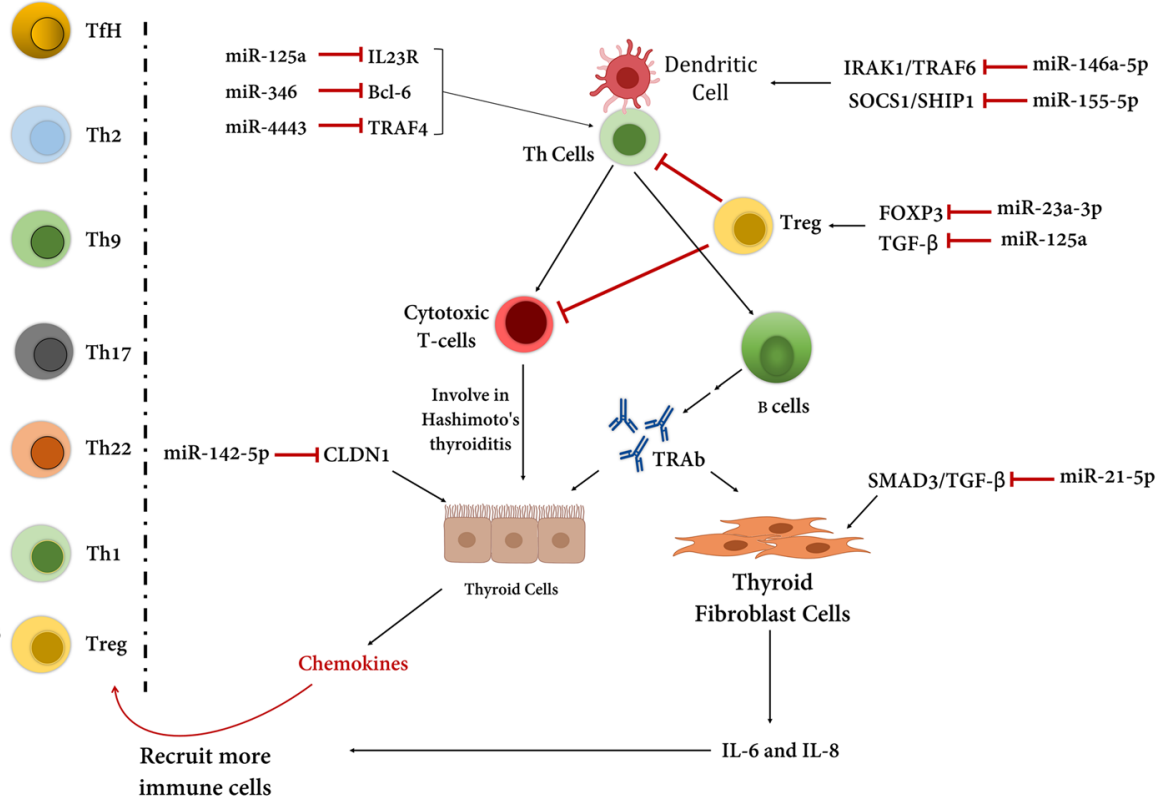

(A) The development of T cells depends on the stimulation/expression of various genes, for example, ILs. Naive CD4+ T cells activated by dendritic cells (DC) can be differentiated into various T cells. Under normal conditions, normal functions of T cells maintain immune tolerance (immune homeostasis). In this figure, TfH, follicular helper T cells; Th, CD4+ T helper (Th) cells; and Treg, regulatory T cells. The figure is redrawn from Wang et al. (2017a). (B) The aberrant expression of miRNAs can lead to breaking down of immune homeostasis that, in turn, causes immune attacks toward thyroid tissues during the GD development. For example, miR-146a-5p can inhibit the IL-1R-associated kinase 1 (IRAK1) and TNF-receptor-associated factor 6 (TRAF6) that are critical for dendritic cell maturation and development (Kobayashi et al. 2003). FOXP3, determining natural Treg development and function, can be repressed by miR-23a-3p. Although cytotoxic T cells do not play a role in GD, they malfunction in Hashimoto's disease. Thyroid fibroblast cells are often involved in graves ophthalmopathy and they can increase the expression of IL- 6 and IL-8 that along with other chemokines contribute to recruiting other immune cells. MiR-142-5p targeting CLDN1 results in the reduced expression of claudin-1 and also increased permeability of thyrocytes monolayer. Overexpression of miR-142-5p in thyrocytes has been reported in GD patients. The figure is redrawn (Wang et al. 2017a). A full color version of this figure is available at https://doi.org/10.1530/JME-20-0078.

mRNA molecules. They often bind to $3^{\prime}$-UTR of target mRNAs and influence their translational efficiency. At least $60 \%$ of human genes contain target sites for miRNAs. Regarding GD, it has been identified that the differential expression of let-7b and miR-146a-5p in GD patients in comparison with controls is associated with GD development. miR-146a-5p is positively associated with TSHR-Abs, suggesting that let-7b and miR-146a-5p may serve as a biomarker for diagnosis and follow-up of GD patients (Al-Heety et al. 2020) (Fig. 3B). miRNAs can predict the predisposition of a worsening clinical outcome in patients with GD. For instance, miR-let7d-5p, miR-21-5p, miR-96-5p, miR-142-3p, and miR-301a-3p are significantly expressed in AITD and especially in GD patients, and can be implied as an indicator of higher severity of disease including active ophthalmopathy, goiter, higher antibody titers, and/or higher recurrence rates (MartínezHernández et al. 2018). Dendritic cells (DC), as an antigenpresenting cell, can activate naive $\mathrm{CD}^{+} \mathrm{T}$ cells which in turn differentiate into various $\mathrm{T}$ helper subsets that are characterized by different cytokine profiles and specific transcription factors. The balance of those immune cells is imperative for the maintenance of immune homeostasis (Fig. 4A). It seems that dysregulated miRNAs can change this homeostasis toward thyroid diseases (Fig. 4B). Aberrant miRNA expression is often detectable in AITDs; however, little information is provided about the miRNAs' contribution to GD. In this review, we summarized some important miRNAs that show aberrant expression in AITD, particularly GD (Table 3).

Aberrant lncRNAs expression or function has been also reported to contribute to GD development; lncRNAs are non-coding RNAs that length more than 200 nucleotides. For example, HCP5 encodes a lncRNA and in terms of the sequence, this gene is pertinent to human endogenous retroviruses HERV-L and HERV-16. Interestingly, this gene is located within the MHC class I region. The encoded lncRNA is involved in adaptive and innate immune responses and is associated with the induction of some autoimmune diseases (Kulski 2019). Several variants in this gene have been linked to drugrelated Stevens-Johnson syndrome, SLE, Kawasaki disease, 
Table 3 Most important microRNAs (miRs) that have a great association with AITDs.

\begin{tabular}{|c|c|c|c|c|c|}
\hline Non-coding RNAs & $\begin{array}{l}\text { Abnormal } \\
\text { expression }(\uparrow \text { or } \downarrow)\end{array}$ & Sample type & Function & AITD & Reference \\
\hline $\begin{array}{l}\text { miR-200, miR-34a, } \\
\text { miR-143, miR-1238 }\end{array}$ & ND & $\begin{array}{l}\text { PBMC of GD } \\
\text { patients and } \\
\text { healthy individual }\end{array}$ & NR & AITD, GD & (Glinsky 2008) \\
\hline $\begin{array}{l}\text { miR-154-5p, miR-376b, } \\
\text { and miR-431-5p }\end{array}$ & $\downarrow$ & $\begin{array}{l}\text { PBMC of GD } \\
\text { patients and } \\
\text { healthy individual }\end{array}$ & NR & GD & (Liu et al. 2012) \\
\hline miR-200a1 & $\uparrow$ & $\begin{array}{l}\text { Thyroid tissue of } \\
\text { HT and GD } \\
\text { patients }\end{array}$ & NR & GD, HT & $\begin{array}{l}\text { (Bernecker et al. } \\
\text { 2012) }\end{array}$ \\
\hline miR-146a1 & $\downarrow$ & $\begin{array}{l}\text { Thyroid tissue of } \\
\text { GD patients }\end{array}$ & NR & GD & $\begin{array}{l}\text { (Bernecker et al. } \\
\text { 2012) }\end{array}$ \\
\hline miR-155 & $\uparrow$ & PBMC, Fibroblasts & $\begin{array}{l}\text { Increased miR-155 promotes ocular } \\
\text { inflammation. }\end{array}$ & $\mathrm{GD}, \mathrm{GO}$ & (Li et al. 2014) \\
\hline miR-146a & $\downarrow$ & PBMC, Fibroblasts & $\begin{array}{l}\text { Decreased miR-146a may promote } \\
\text { ocular inflammation and proliferation } \\
\text { in GO patients. }\end{array}$ & GD, GO & (Li et al. 2014) \\
\hline $\begin{array}{l}\text { miR-200a_1, miR- } \\
\text { 200a2-5p, miR-155 }\end{array}$ & $\downarrow$ & CD4+ T cells & $\begin{array}{l}\text { miR-155 can modulate the } \\
\text { differentiation and function of cells of } \\
\text { the innate and adaptive immunity and } \\
\text { also can downregulate SMAD4 in } \\
\text { PBMCs of GD patients. }\end{array}$ & GD, HT & $\begin{array}{l}\text { (Bernecker et al. } \\
\text { 2014) }\end{array}$ \\
\hline miR-125a & $\downarrow$ & PBMCs & $\begin{array}{l}\text { miR-125a acts as a negative regulator of } \\
\text { interleukin (IL)- } 6 \text { and transforming } \\
\text { growth factor (TGF)- } \beta \text {. }\end{array}$ & HD, AITD, GD & $\begin{array}{l}\text { (Inoue et al. 2014, } \\
\text { Peng et al. 2015) }\end{array}$ \\
\hline miR-22, miR-183 & $\uparrow$ & $\begin{array}{l}\text { Specimens of } \\
\text { thyroid tissue } \\
\text { from GD patients }\end{array}$ & $\begin{array}{l}\text { miR-22 targets estrogen receptor alpha } \\
\text { mRNA, resulting in the repression of } \\
\text { estrogen signaling, which is required } \\
\text { for T cell differentiation. miR-183 is a } \\
\text { key factor in TGF- } \beta 1 \text {-mediated immune } \\
\text { suppression. }\end{array}$ & GD & (Qin et al. 2015) \\
\hline $\begin{array}{l}\text { miR-101, miR-197, } \\
\text { miR-660 }\end{array}$ & $\downarrow$ & $\begin{array}{l}\text { Specimens of } \\
\text { thyroid tissue } \\
\text { from GD patients }\end{array}$ & $\begin{array}{l}\text { miR-101 targets JAK/STAT and nuclear } \\
\text { factor-kappa B (NF-kB) pathway } \\
\text { inhibitors, so can change TNF } \\
\text { production. miR-197 targets CILP and } \\
\text { IL6R that are upregulated in GD. No } \\
\text { conclusive roles of miR-660 in GD } \\
\text { pathogenesis were detected. }\end{array}$ & GD & (Qin et al. 2015) \\
\hline miR-346 & $\uparrow$ & $\begin{array}{l}\text { circulating } \mathrm{CD}^{+} \mathrm{T} \\
\text { cells and plasma }\end{array}$ & $\begin{array}{l}\text { miR-346 inhibits } \mathrm{BCl}-6 \text { expression and } \\
\text { regulates the activation of } \mathrm{CD} 4^{+} \mathrm{T} \text { cells. }\end{array}$ & GD & (Chen et al. 2015) \\
\hline miR-224-5p & $\downarrow$ & $\begin{array}{l}\text { Serum of GD and } \\
\text { GO patients }\end{array}$ & $\begin{array}{l}\text { overexpression of miR-224-5p can } \\
\text { restore glucocorticoid sensitivity via } \\
\text { targeting GSK-3beta in GO cell models }\end{array}$ & $\mathrm{GD}, \mathrm{GO}$ & (Shen et al. 2015) \\
\hline miR-23b-5p, miR-92a-39 & $\uparrow$ & $\begin{array}{l}\text { PBMC of GD } \\
\text { patients after and } \\
\text { before remission }\end{array}$ & $\begin{array}{l}\text { miR-23b regulates NF-kB signaling } \\
\text { pathway in GD, while miR-92a induces } \\
\text { IL-6+ IL-10+ Natural Killer Cells, } \\
\text { suppressing cytotoxic CD8+ T cells. }\end{array}$ & GD & $\begin{array}{l}\text { (Hiratsuka et al. } \\
\text { 2016) }\end{array}$ \\
\hline let-7g-3p and miR-339-5p & $\downarrow$ & $\begin{array}{l}\text { PBMC of GD } \\
\text { patients after and } \\
\text { before remission }\end{array}$ & $\begin{array}{l}\text { They can upregulate cytokine production } \\
\text { in GD patients. }\end{array}$ & GD & $\begin{array}{l}\text { (Hiratsuka et al. } \\
\text { 2016) }\end{array}$ \\
\hline let-7e & $\uparrow$ & PBMC & $\begin{array}{l}\text { let-7e regulates intracellular IL-10 } \\
\text { expression in HD patients. }\end{array}$ & HD, GD & (Kagawa et al. 2016) \\
\hline $\begin{array}{l}\text { miR-4443, miR-10a, } \\
\text { miR-125b }\end{array}$ & $\downarrow$ & $\begin{array}{l}\text { CD4+ T cells from } \\
\text { untreated GD } \\
\text { (UGD) patients }\end{array}$ & $\begin{array}{l}\text { miR-4443 causes CD4+ } T \text { cells } \\
\text { dysfunction by targeting TNFR- } \\
\text { associated factor } 4 \text { in GD. No } \\
\text { molecular function of miR-10a and } \\
\text {-125b was detected in GD. }\end{array}$ & GD & (Qi et al. 2017) \\
\hline miR-1a & $\downarrow$ & $\begin{array}{l}\text { Serum of GD } \\
\text { patients }\end{array}$ & NR & GD & (Wang et al. 2017b) \\
\hline $\begin{array}{l}\text { miR-16-1-3p, miR-122-5p, } \\
\text { miR-221-3p, miR-762 }\end{array}$ & $\uparrow$ & Plasma & NR & GD & (Yao et al. 2019b) \\
\hline miR-23a-3p & $\downarrow$ & PBMC & NR & GD & (Zhang et al. 2019) \\
\hline miR-21-5p & $\uparrow$ & Plasma & $\begin{array}{l}\text { miR-21-5p regulates lymphocyte } \\
\text { differentiation and activation in GD } \\
\text { patients. }\end{array}$ & GD, GO & (Al-Heety et al. 2020) \\
\hline
\end{tabular}

GD, Graves' disease; GO, Graves ophthalmopathy; HD, Hashimoto's disease; HT, Hashimoto's thyroiditis; NR, not reported; PBMC, peripheral blood mononuclear cell. 
and psoriasis (reviewed in Kus et al. 2019). Regarding AITD, HCP5 rs3094228 polymorphism has been reported in association with TPO antibody levels and also GD susceptibility in Polish-Caucasian populations (Kuś et al. 2015). The number of HCP5 risk alleles is inversely associated with the age of GD onset. This suggests HCP5 as one of the GD risk loci. LncRNA Heg, as a GD-associated lncRNA, was demonstrated by Christensen et al. and was found to be related to the degree of mRNA as well as CD14 TRAb in mononuclear cells of GD patients (Christensen et al. 2008). Some lncRNAs are limited to AITDs and their roles in GD are still unclear. For example, SAS-ZFAT, an antisense transcript of the ZFAT gene, was reported to increase susceptibility to AITD (reviewed in Wu et al. 2015). How the lncRNAs regulating network affects GD mechanisms is still elusive and we believe that it is an important point for or discussion and further research.

\section{Exosomes}

Extracellular vesicles (EVs) can be in a range of 50-200 nm (Bæk et al. 2016). EVs are secreted by all cells and play roles in various physiological functions containing signaling, communication, and defense (Stahl \& Raposo 2019). It has been shown that exosomes and their pertinent molecules, such as proteins and miRNAs, are tightly correlated with the pathogenesis in the majority of human malignancies. Exosomes have been also recently shown to play roles in the pathogenesis of GD. For example, Hiratsuka et al. showed that exosomes from intractable GD patients stimulated mRNA expression for IL- $1 \beta$ and TNF- $\alpha$ compared with GD patients in remission or healthy controls. Thus, it seems that serum exosomes of patients with intractable GD can activate immune cells, which in turn play an important role in GD pathogenesis (Hiratsuka et al. 2016). It has been also discussed that thyrocyte-derived exosometargeted dendritic cells (harbored TPO, heat shock protein 60, MHC-II, and activated dendritic cells) can strongly stimulate $\mathrm{CD}^{+}{ }^{+} \mathrm{T}$ lymphocyte responses and play a role in the occurrence and development of AITD (Cui et al. 2020). This study increases the chance of establishing a proper therapeutic approach to treat AITD, therefore, future research should be conducted in more realistic settings to support this need.

\section{Conclusions and future perspectives}

Global efforts have been committed to elucidating the susceptibility loci that are responsible for GD risk ever since genetics were identified as a contributing factor to AITD susceptibility. Even though there are currently numerous associated genes, figuring out the disease etiopathogenesis will be improved with cutting-edge technologies and universal endeavors that are developed to a wide range of novel genes, variants, and various contributing factors. The synchronized genome-wide assay of gene expression, GWAS, and using next-generation sequencing techniques allow mapping of the genetic contributors that emphasize individual differences in quantitative levels of expression. In addition to genetic factors, the contribution of epigenetic modifications to GD pathogenesis should be addressed more than before, as data are lacking in this regard. The vital issue now is to specify how these novel discovered variants and epigenetic modifications influence GD pathogenesis. The functional analysis of these genes will provide more opportunities to convert these genetic findings into a better understanding of GD pathogenesis and apply them to devise new potential therapeutic options.

In this review, we observed that there are various possible genes and epigenetic modifications that are related to GD development and/or susceptibility. These observations raise very fundamental questions of how these genes, encoded proteins, or RNAs play role in a tortuous network of signaling pathways that contribute to GD initiation or development. We also realize that some points of GD etiology remain to be discovered; for example, how epigenetic modulations in combination with genetic and environmental interventions play roles in GD. Not much is known about why there is a great difference between susceptible loci in different populations; are there environmental factors (e.g. specific dietary habits) modulating susceptibility to GD? Most applied studies to GD have been performed by using small populations which is, in turn, a drawback of such studies; however, we believe that coming investigations will cast light on GD, which in turn provides valuable information about different biological aspects of 'GD etiology' and will pave the way to utilize them effectively in therapeutic purposes.

\section{Declaration of interest}

The authors declare that no conflict of interest could be perceived as prejudicing the impartiality of this review.

\section{Author contribution statement}

$\mathrm{ER}$ and $\mathrm{M} M$ involved in conceptualization. $E R, A R B, H Y$ and $M S$ contributed to methodology of the study. M S, M M, S A, A R B, JR C and $H Y$ involved in the validation of the data. E R, A R B and MS involved in the 
writing - original draft preparation. A R B $H Y, M M, J R C$ and $S A$ involved in the writing - review and editing. E R and A R B involved in visualization. M M involved in the supervision. All authors approved final version of the article.

\section{Acknowledgements}

The authors thank Dr Sadegh Babashah, Tarbiat Modares University, Tehran, Iran, for his comments. Furthermore, the authors appreciate $\mathrm{Mr}$ Milad Sabzevary, Shahrekord University of Medical Sciences, Shahrekord, Iran, for editing this paper.

\section{References}

Al-Heety RA, Al-Hadithi HS \& Turki KM 2020 Correlation of circulating miRNA-146a-5p and let-7b expression with thyroid-stimulating hormone receptor antibody in patients with graves disease. Gene Reports 19 100608. (https://doi.org/10.1016/j.genrep.2020.100608)

Antonelli A, Ferrari SM, Giuggioli D, Di Domenicantonio A, Ruffilli I, Corrado A, Fabiani S, Marchi S, Ferri C, Ferrannini E, et al. 2014 Hepatitis $\mathrm{C}$ virus infection and type 1 and type 2 diabetes mellitus. World Journal of Diabetes 5 586-600. (https://doi.org/10.4239/wjd. v5.i5.586)

Antonelli A, Ferrari SM, Corrado A, Di Domenicantonio A \& Fallahi P 2015 Autoimmune thyroid disorders. Autoimmunity Reviews 14 174-180. (https://doi.org/10.1016/j.autrev.2014.10.016)

Anvari M, Khalilzadeh O, Esteghamati A, Momen-Heravi F, Mahmoudi M, Esfahani SA, Rashidi A \& Amirzargar A 2010 Graves' disease and gene polymorphism of TNF-alpha, IL-2, IL-6, IL-12, and IFN-gamma. Endocrine 37 344-348. (https://doi.org/10.1007/s12020010-9311-y)

Arakawa Y, Watanabe M, Inoue N, Sarumaru M, Hidaka Y \& Iwatani Y 2012 Association of polymorphisms in DNMT1, DNMT3A, DNMT3B, MTHFR and MTRR genes with global DNA methylation levels and prognosis of autoimmune thyroid disease. Clinical and Experimental Immunology 170 194-201. (https://doi. org/10.1111/j.1365-2249.2012.04646.x)

Bæk R, Søndergaard EK, Varming K \& Jørgensen MM 2016 The impact of various preanalytical treatments on the phenotype of small extracellular vesicles in blood analyzed by protein microarray. Journal of Immunological Methods 438 11-20. (https://doi.org/10.1016/j. jim.2016.08.007)

Ban Y, Greenberg DA, Concepcion ES \& Tomer Y 2002 A germline single nucleotide polymorphism at the intracellular domain of the human thyrotropin receptor does not have a major effect on the development of Graves' disease. Thyroid 12 1079-1083. (https://doi. org/10.1089/105072502321085171)

Ban Y, Greenberg DA, Concepcion E, Skrabanek L, Villanueva R \& Tomer Y 2003 Amino acid substitutions in the thyroglobulin gene are associated with susceptibility to human and murine autoimmune thyroid disease. PNAS 100 15119-15124. (https://doi.org/10.1073/ pnas.2434175100)

Ban Y, Tozaki T \& Taniyama M 2013 The replication of the association of the rs9355610 within 6p27 with Graves' disease. Autoimmunity 46 395-398. (https://doi.org/10.3109/08916934.2013.780600)

Bednarczuk T, Placha G, Jazdzewski K, Kurylowicz A, Kloza M, Makowska U, Hiromatsu Y \& Nauman J 2003 Interleukin-13 gene polymorphisms in patients with Graves' disease. Clinical Endocrinology 59 519-525. (https://doi. org/10.1046/j.1365-2265.2003.01880.x)

Begum MN, Islam MT, Hossain SR, Bhuyan GS, Halim MA, Shahriar I, Sarker SK, Haque S, Konika TK, Islam MS, et al. 2019 Mutation spectrum in TPO gene of Bangladeshi patients with thyroid dyshormonogenesis and analysis of the effects of different mutations on the structural features and functions of TPO protein through in silico approach. BioMed Research International 20199218903. (https://doi.org/10.1155/2019/9218903)

Bernecker C, Lenz L, Ostapczuk MS, Schinner S, Willenberg H, Ehlers M, Vordenbäumen S, Feldkamp J \& Schott M 2012 MicroRNAs miR146a1, miR-155_2, and miR-200a1 are regulated in autoimmune thyroid diseases. Thyroid 22 1294-1295. (https://doi.org/10.1089/ thy.2012.0277)

Bernecker C, Halim F, Lenz L, Haase M, Nguyen T, Ehlers M, Vordenbaeumen S \& Schott M 2014 MicroRNA expressions in CD4+ and CD8+ T-cell subsets in autoimmune thyroid diseases. Experimental and Clinical Endocrinology and Diabetes 122 107-112. (https://doi.org/10.1055/s-0033-1361088)

Bottazzo G, Hanafusa T, Pujol-Borrell R \& Feldmann M 1983 Role of aberrant HLA-DR expression and antigen presentation in induction of endocrine autoimmunity. Lancet 322 1115-1119. (https://doi. org/10.1016/s0140-6736(83)90629-3)

Bottini N \& Peterson EJ 2014 Tyrosine phosphatase PTPN22: multifunctional regulator of immune signaling, development, and disease. Annual Review of Immunology 32 83-119. (https://doi. org/10.1146/annurev-immunol-032713-120249)

Brand OJ, Barrett JC, Simmonds MJ, Newby PR, McCabe CJ, Bruce CK, Kysela B, Carr-Smith JD, Brix T, Hunt PJ, et al. 2009 Association of the thyroid stimulating hormone receptor gene (TSHR) with Graves' disease. Human Molecular Genetics 18 1704-1713. (https://doi. org/10.1093/hmg/ddp087)

Brent GA 2008 Graves' disease. New England Journal of Medicine 358 2594-2605. (https://doi.org/10.1056/NEJMcp0801880)

Bufalo NE, Dos Santos RB, Marcello MA, Piai RP, Secolin R, Romaldini JH \& Ward LS 2015 TSHR intronic polymorphisms (rs179247 and rs12885526) and their role in the susceptibility of the Brazilian population to Graves' disease and Graves' ophthalmopathy. Journal of Endocrinological Investigation 38 555-561. (https://doi.org/10.1007/ s40618-014-0228-9)

Cai TT, Muhali FS, Song RH, Qin Q, Wang X, Shi LF, Jiang WJ, Xiao L, Li DF \& Zhang JA 2015 Genome-wide DNA methylation analysis in Graves' disease. Genomics 105 204-210. (https://doi.org/10.1016/j. ygeno.2015.01.001)

Campbell P, Brix TH, Wilson SG, Ward LC, Hui J, Beilby JP, Hegedüs L \& Walsh JP 2016 Common genetic variants associated with thyroid function may be risk alleles for Hashimoto's disease and Graves' disease. Clinical Endocrinology 84 278-283. (https://doi.org/10.1111/ cen.12746)

Campi I, Tosi D, Rossi S, Vannucchi G, Covelli D, Colombo F, Trombetta E, Porretti L, Vicentini L, Cantoni G, et al. 2015 B cell activating factor (BAFF) and BAFF receptor expression in autoimmune and nonautoimmune thyroid diseases. Thyroid $\mathbf{2 5}$ 1043-1049. (https://doi.org/10.1089/thy.2015.0029)

Castanet M \& Polak M 2010 Spectrum of human Foxe1/TTF2 mutations. Hormone Research in Paediatrics 73 423-429. (https://doi. org/10.1159/000281438)

Chen Q 2019 The expression of interleukin-15 and interleukin-17 in tears and orbital tissues of Graves ophthalmopathy patients. Journal of Cellular Biochemistry 120 6299-6303. (https://doi.org/10.1002/ jcb.27916)

Chen QY, Nadell D, Zhang XY, Kukreja A, Huang YJ, Wise J, Svec F, Richards R, Friday KE, Vargas A, et al. 2000 The human leukocyte antigen HLA DRB3 $* 0202 /$ DQA $1 * 0501$ haplotype is associated with Graves' disease in African Americans. Journal of Clinical Endocrinology and Metabolism 85 1545-1549. (https://doi.org/10.1210/ jcem.85.4.6523)

Chen RH, Chen WC, Chang CT, Tsai CH \& Tsai FJ 2005 Interleukin-1- $\beta$ gene, but not the interleukin-1 receptor antagonist gene, is associated with Graves' disease. Journal of Clinical Laboratory Analysis 19 133-138. (https://doi.org/10.1002/jcla.20067)

Chen J, Tian J, Tang X, Rui K, Ma J, Mao C, Liu Y, Lu L, Xu H \& Wang S 2015 MiR-346 regulates CD4+ CXCR5+ T cells in the pathogenesis of 
Graves' disease. Endocrine 49 752-760. (https://doi.org/10.1007/ s12020-015-0546-5)

Chen X, Huang F, Qi Y, Zhou M, Yin Q, Peng Y, Zhou Y, Ning G \& Wang S 2018 Serum and thyroid tissue level of let-7b and their correlation with TRAb in Graves' disease. Journal of Translational Medicine 16 188. (https://doi.org/10.1186/s12967-018-1565-9)

Chistiakov DA, Voronova NV, Turakulov RI \& Savost'anov KV 2011 The $-112 \mathrm{G}>$ a polymorphism of the secretoglobin 3A2 (SCGB3A2) gene encoding uteroglobin-related protein 1 (UGRP1) increases risk for the development of Graves' disease in subsets of patients with elevated levels of immunoglobulin E. Journal of Applied Genetics $\mathbf{5 2}$ 201-207. (https://doi.org/10.1007/s13353-010-0022-0)

Christensen NJ, Habekost G \& Bratholm P 2008 A RNA transcript (Heg) in mononuclear cells is negatively correlated with CD14 mRNA and TSH receptor autoantibodies. Clinical and Experimental Immunology 154 209-215. (https://doi.org/10.1111/j.1365-2249.2008.03744.x)

Chu X, Pan CM, Zhao SX, Liang J, Gao GQ, Zhang XM, Yuan GY, Li CG, Xue LQ, Shen M, et al. 2011 A genome-wide association study identifies two new risk loci for Graves' disease. Nature Genetics 43 897-901. (https://doi.org/10.1038/ng.898)

Colobran R, Armengol Mdel P, Faner R, Gärtner M, Tykocinski LO, Lucas A, Ruiz M, Juan M, Kyewski B \& Pujol-Borrell R 2011 Association of an SNP with intrathymic transcription of TSHR and Graves' disease: a role for defective thymic tolerance. Human Molecular Genetics 20 3415-3423. (https://doi.org/10.1093/hmg/ddr247)

Cooper JD, Smyth DJ, Smiles AM, Plagnol V, Walker NM, Allen JE, Downes K, Barrett JC, Healy BC, Mychaleckyj JC, et al. 2008 Metaanalysis of genome-wide association study data identifies additional type 1 diabetes risk loci. Nature Genetics 40 1399-1401. (https://doi. org/10.1038/ng.249)

Cooper JD, Simmonds MJ, Walker NM, Burren O, Brand OJ, Guo H, Wallace C, Stevens H, Coleman G, Wellcome Trust Case Control Consortium, et al. 2012 Seven newly identified loci for autoimmune thyroid disease. Human Molecular Genetics 21 5202-5208. (https:// doi.org/10.1093/hmg/dds357)

Coppedè F 2017 Epigenetics and autoimmune thyroid diseases. Frontiers in Endocrinology 8 149. (https://doi.org/10.3389/ fendo.2017.00149)

Cuddihy RM \& Bahn RS 1996 Lack of an association between alleles of interleukin-1 alpha and interleukin-1 receptor antagonist genes and Graves' disease in a North American Caucasian population. Journal of Clinical Endocrinology and Metabolism 81 4476-4478. (https://doi. org/10.1210/jcem.81.12.8954062)

Cuddihy RM, Dutton CM \& Bahn RS 1995 A polymorphism in the extracellular domain of the thyrotropin receptor is highly associated with autoimmune thyroid disease in females. Thyroid 5 89-95. (https://doi.org/10.1089/thy.1995.5.89)

Cui X, Wang S, Zhao N, Wang S, Wang Z, Huang M, Liu Y, Qin J, Shan Z, Teng W, et al. 2020 Thyrocyte-derived exosome-targeted dendritic cells stimulate strong CD4+ T lymphocyte responses. Molecular and Cellular Endocrinology 506 110756. (https://doi. org/10.1016/j.mce.2020.110756)

Danoy P, Wei M, Johanna H, Jiang L, He D, Sun L, Zeng X, Visscher PM, Brown MA \& Xu H 2011 Association of variants in MMEL1 and CTLA4 with rheumatoid arthritis in the Han Chinese population. Annals of the Rheumatic Diseases 70 1793-1797. (https://doi. org/10.1136/ard.2010.144576)

Dechairo BM, Zabaneh D, Collins J, Brand O, Dawson GJ, Green AP, Mackay I, Franklyn JA, Connell JM, Wass JA, et al. 2005 Association of the TSHR gene with Graves' disease: the first disease specific locus. European Journal of Human Genetics 13 1223-1230. (https://doi. org/10.1038/sj.ejhg.5201485)

Deng Q, Luo Y, Chang C, Wu H, Ding Y \& Xiao R 2019 The emerging epigenetic role of CD8+ T cells in autoimmune diseases: a systematic review. Frontiers in Immunology 10 856. (https://doi.org/10.3389/ fimmu.2019.00856)
Devarajan P 2014 Regulation of CD4+ autoimmune memory by CTLA4. Doctoral dissertation, University of Miami.

Dubois PC, Trynka G, Franke L, Hunt KA, Romanos J, Curtotti A, Zhernakova A, Heap GA, Ádány R, Aromaa A, et al. 2010 Multiple common variants for celiac disease influencing immune gene expression. Nature Genetics 42 295-302. (https://doi.org/10.1038/ng.543)

Fang Y, Li Y, Zeng J, Wang J, Liu R \& Cao C 2016 Genetic association of Fc receptor-like glycoprotein with susceptibility to Graves' disease in a Chinese Han population. Immunobiology 221 56-62. (https://doi. org/10.1016/j.imbio.2015.08.002)

Ferrari S, Giliani S, Insalaco A, Al-Ghonaium A, Soresina AR, Loubser M, Avanzini MA, Marconi M, Badolato R, Ugazio AG, et al. 2001 Mutations of CD40 gene cause an autosomal recessive form of immunodeficiency with hyper IgM. PNAS 98 12614-12619. (https:// doi.org/10.1073/pnas.221456898)

Fujii A, Inoue N, Watanabe M, Kawakami C, Hidaka Y, Hayashizaki Y \& Iwatani Y 2017 TSHR gene polymorphisms in the enhancer regions are most strongly associated with the development of Graves' disease, especially intractable disease, and of Hashimoto's disease. Thyroid 27 111-119. (https://doi.org/10.1089/ thy.2016.0345)

Galligan TM, Hale MD, McCoy JA, Bermudez DS, Guillette Jr LJ \& Parrott BB 2019 Assessing impacts of precocious steroid exposure on thyroid physiology and gene expression patterns in the American alligator (Alligator mississippiensis). General and Comparative Endocrinology 271 61-72. (https://doi.org/10.1016/j. ygcen.2018.11.002)

Genere N \& Stan MN 2019 Current and emerging treatment strategies for graves' orbitopathy. Drugs 79 109-124. (https://doi.org/10.1007/ s40265-018-1045-9)

Glinsky GV 2008 An SNP-guided microRNA map of fifteen common human disorders identifies a consensus disease phenocode aiming at principal components of the nuclear import pathway. Cell Cycle $\mathbf{7}$ 2570-2583. (https://doi.org/10.4161/cc.7.16.6524)

Grasberger H, Ringkananont U, LeFrancois P, Abramowicz M, Vassart G \& Refetoff S 2005 Thyroid transcription factor 1 rescues PAX8/p300 synergism impaired by a natural PAX8 paired domain mutation with dominant negative activity. Molecular Endocrinology 19 1779-1791. (https://doi.org/10.1210/me.2004-0426)

Gu XJ, Cui B, Zhao ZF, Chen HY, Li XY, Wang S, Ning G \& Zhao YJ 2008 Association of the interleukin (IL)-16 gene polymorphisms with Graves' disease. Clinical Immunology 127 298-302. (https://doi. org/10.1016/j.clim.2008.01.017)

Gu LQ, Zhu W, Zhao SX, Zhao L, Zhang MJ, Cui B, Song HD, Ning G \& Zhao YJ 2010 Clinical associations of the genetic variants of CTLA-4, Tg, TSHR, PTPN22, PTPN12 and FCRL3 in patients with Graves' disease. Clinical Endocrinology 72 248-255. (https://doi. org/10.1111/j.1365-2265.2009.03617.x)

Hamilton A, Gough SC \& Simmonds MJ 2013 Genetics of Graves disease. eLS 9 121-138. (https://doi.org/10.1002/9780470015902. a0024977)

Heward JM, Nithiyananthan R, Allahabadia A, Gibson S, Franklyn JA \& Gough SC 2001 No association of an interleukin 4 gene promoter polymorphism with Graves' disease in the United Kingdom. Journal of Clinical Endocrinology and Metabolism 86 3861-3863. (https://doi. org/10.1210/jcem.86.8.7744)

Hiratani H, Bowden DW, Ikegami S, Shirasawa S, Shimizu A, Iwatani Y \& Akamizu T 2005 Multiple SNPs in intron 7 of thyrotropin receptor are associated with Graves' disease. Journal of Clinical Endocrinology and Metabolism 90 2898-2903. (https://doi.org/10.1210/jc.2004-2148)

Hiratsuka I, Yamada H, Munetsuna E, Hashimoto S \& Itoh M 2016 Circulating microRNAs in Graves' disease in relation to clinical activity. Thyroid 26 1431-1440. (https://doi.org/10.1089/ thy.2016.0062)

Hiromatsu Y, Fukutani T, Ichimura M, Mukai T, Kaku H, Nakayama H, Miyake I, Shoji S, Koda Y \& Bednarczuk T 2005 Interleukin-13 gene 
polymorphisms confer the susceptibility of Japanese populations to Graves' disease. Journal of Clinical Endocrinology and Metabolism 90 296-301. (https://doi.org/10.1210/jc.2004-0931)

Hodge SE, Ban Y, Strug LJ, Greenberg DA, Davies TF, Concepcion ES, Villanueva R \& Tomer Y 2006 Possible interaction between HLA-DR $\beta 1$ and thyroglobulin variants in Graves' disease. Thyroid $\mathbf{1 6}$ 351-355. (https://doi.org/10.1089/thy.2006.16.351)

Hom G, Graham RR, Modrek B, Taylor KE, Ortmann W, Garnier S, Lee AT, Chung SA, Ferreira RC, Pant PV, et al. 2008 Association of systemic lupus erythematosus with C8orf13-BLK and ITGAMITGAX. New England Journal of Medicine 358 900-909. (https://doi. org/10.1056/NEJMoa0707865)

Houston FA, Wilson V, Jennings CE, Owen CJ, Donaldson P, Perros P \& Pearce SH 2004 Role of the CD40 locus in Graves' disease. Thyroid 14 506-509. (https://doi.org/10.1089/1050725041517039)

Huang CJ \& Jap TS 2015 A systematic review of genetic studies of thyroid disorders in Taiwan. Journal of the Chinese Medical Association 78 145-153. (https://doi.org/10.1016/j. jcma.2014.09.010)

Huber AK, Jacobson EM, Jazdzewski K, Concepcion ES \& Tomer Y 2008 Interleukin (IL)-23 receptor is a major susceptibility gene for Graves' ophthalmopathy: the IL-23/T-helper 17 axis extends to thyroid autoimmunity. Journal of Clinical Endocrinology and Metabolism 93 1077-1081. (https://doi.org/10.1210/jc.2007-2190)

Imani D, Rezaei R, Razi B, Alizadeh S \& Mahmoudi M 2017 Association between IL6-174 G/C polymorphism and Graves' disease: a systematic review and meta-analysis. Acta Medica Iranica 55 665-671.

Inoue Y, Watanabe M, Inoue N, Kagawa T, Shibutani S, Otsu H, Saeki M, Takuse Y, Hidaka Y \& Iwatani Y 2014 Associations of single nucleotide polymorphisms in precursor-microRNA (miR)-125a and the expression of mature mi R-125a with the development and prognosis of autoimmune thyroid diseases. Clinical and Experimental Immunology 178 229-235. (https://doi.org/10.1111/cei.12410)

International Multiple Sclerosis Genetics Consortium, Wellcome Trust Case Control Consortium 2, Sawcer S, Hellenthal G, Pirinen M, Spencer CC, Patsopoulos NA, Moutsianas L, Dilthey A, Su Z, et al. 2011 Genetic risk and a primary role for cell-mediated immune mechanisms in multiple sclerosis. Nature 476 214-219. (https://doi. org/10.1038/nature10251)

Jacobson EM, Huber AK, Akeno N, Sivak M, Li CW, Concepcion E, Ho K \& Tomer Y 2007 A CD40 Kozak sequence polymorphism and susceptibility to antibody-mediated autoimmune conditions: the role of CD40 tissue-specific expression. Genes and Immunity 8 205-214. (https://doi.org/10.1038/sj.gene.6364375)

Jin Y, Birlea SA, Fain PR, Ferrara TM, Ben S, Riccardi SL, Cole JB, Gowan K, Holland PJ, Bennett DC, et al. 2012 Genome-wide association analyses identify 13 new susceptibility loci for generalized vitiligo. Nature Genetics 44 676-680. (https://doi.org/10.1038/ng.2272)

Jin GX, Zhou YY, Yu L \& Bi YX 2015 Correlation between single nucleotide polymorphism of FCRL-3 gene and Graves' disease in Han population of northern Anhui Province, China. International Journal of Clinical and Experimental Medicine 8 12624-12630.

Jing W, Sun W, Zhang X, Zhao W, Wanyu G, Zhao S, Shi Z \& Xiaolei H 2016 Association of TSHR gene intron 1 and 4 p14 single-nucleotide polymorphisms and gene-gene interactions with Graves' disease. Chinese Journal of Endocrinology and Metabolism 32 292-297. (https:// doi.org/10.1038/sj.ejhg.5201485)

Kagawa T, Watanabe M, Inoue N, Otsu H, Saeki M, Katsumata Y, Takuse Y \& Iwatani Y 2016 Increases of microRNA let-7e in peripheral blood mononuclear cells in Hashimoto's disease. Endocrine Journal 63 375-380. (https://doi.org/10.1507/endocrj.EJ15-0577)

Kawashima A, Yamazaki K, Hara T, Akama T, Yoshihara A, Sue M, Tanigawa $\mathrm{K}, \mathrm{Wu} \mathrm{H}$, Ishido $\mathrm{Y}$, Takeshita F, et al. 2013 Demonstration of innate immune responses in the thyroid gland: potential to sense danger and a possible trigger for autoimmune reactions. Thyroid $\mathbf{2 3}$ 477-487. (https://doi.org/10.1089/thy.2011.0480)
Khalilzadeh O, Anvari M, Esteghamati A, Mahmoudi M, Tahvildari M, Rashidi A, Khosravi F \& Amirzargar A 2009 Graves' ophthalmopathy and gene polymorphisms in interleukin- $1 \alpha$, interleukin- $1 \beta$, interleukin-1 receptor and interleukin-1 receptor antagonist. Clinical and Experimental Ophthalmology 37 614-619. (https://doi. org/10.1111/j.1442-9071.2009.02093.x)

Kobayashi T, Walsh PT, Walsh MC, Speirs KM, Chiffoleau E, King CG, Hancock WW, Caamano JH, Hunter CA, Scott P, et al. 2003 TRAF6 is a critical factor for dendritic cell maturation and development. Immunity 19 353-363. (https://doi.org/10.1016/s10747613(03)00230-9)

Kochi Y, Yamada R, Suzuki A, Harley JB, Shirasawa S, Sawada T, Bae SC, Tokuhiro S, Chang X, Sekine A, et al. 2005 A functional variant in FCRL3, encoding Fc receptor-like 3, is associated with rheumatoid arthritis and several autoimmunities. Nature Genetics 37 478-485. (https://doi.org/10.1038/ng1540)

Kopp P \& Solis-S JC 2009 Chapter 3 - Thyroid hormone synthesis. In Clinical Management of Thyroid Disease, pp. 19-41. Eds FE Wondisford \& S Radovick. Philadelphia: W.B. Saunders.

Kopp P, Bizhanova A \& Pesce L 2017 The controversial role of pendrin in thyroid cell function and in the thyroid phenotype in Pendred syndrome. In The Role of Pendrin in Health and Disease, pp. 107-118. Springer. (https://doi.org/10.1007/978-3-319-43287-8_7)

Kulski JK 2019 Long noncoding RNA HCP5, a hybrid HLA Class I endogenous retroviral gene: structure, expression, and disease associations. Cells 8 480. (https://doi.org/10.3390/cells8050480)

Kuo SH, Yeh PY, Chen LT, Wu MS, Lin CW, Yeh KH, Tzeng YS, Chen JY, Hsu PN, Lin JT, et al. 2008 Overexpression of B cell-activating factor of TNF family (BAFF) is associated with Helicobacter pylori independent growth of gastric diffuse large B-cell lymphoma with histologic evidence of MALT lymphoma. Blood 112 2927-2934. (https://doi.org/10.1182/blood-2008-02-137513)

Kursawe R \& Paschke R 2007 Modulation of TSHR signaling by posttranslational modifications. Trends in Endocrinology and Metabolism 18 199-207. (https://doi.org/10.1016/j.tem.2007.05.002)

Kurylowicz A, Kula D, Ploski R, Skorka A, Jurecka-Lubieniecka B, Zebracka J, Steinhof-Radwanska K, Hasse-Lazar K, Hiromatsu Y, Jarzab B, et al. 2005 Association of CD40 gene polymorphism (C-1T) with susceptibility and phenotype of Graves' disease. Thyroid $\mathbf{1 5}$ 1119-1124. (https://doi.org/10.1089/thy.2005.15.1119)

Kuś A, Szymański K, Peeters RP, Miśkiewicz P, Porcu E, Pistis G, Sanna S, Naitza S, Płoski R \& Medici M 2015 The association of thyroid peroxidase antibody risk loci with susceptibility to and phenotype of Graves' disease. Clinical Endocrinology 83 556-562. (https://doi. org/10.1111/cen.12640)

Kuś A, Szymański K, Jurecka-Lubieniecka B, Pawlak-Adamska E, Kula D, Miśkiewicz P, Bolanowski M, Płoski R, Bossowski A, Daroszewski J, et al. 2017 Gender-dependent and age-of-onset-specific association of the rs11675434 single-nucleotide polymorphism near TPO with susceptibility to Graves' ophthalmopathy. Journal of Human Genetics 62 373-377. (https://doi.org/10.1038/jhg.2016.135)

Kus A, Radziszewski M, Glina A, Szymanski K, Jurecka-Lubieniecka B, Pawlak-Adamska E, Kula D, Wawrusiewicz-Kurylonek N, Kus J, Miskiewicz P, et al. 2019 Paediatric-onset and adult-onset Graves' disease share multiple genetic risk factors. Clinical Endocrinology $\mathbf{9 0}$ 320-327. (https://doi.org/10.1111/cen.13887)

Kyewski B \& Klein L 2006 A central role for central tolerance. Annual Review of Immunology 24 571-606. (https://doi.org/10.1146/annurev. immunol.23.021704.115601)

Lane LC, Allinson KR, Campbell K, Bhatnagar I, Ingoe L, Razvi S, Cheetham T, Cordell HJ, Pearce SH \& Mitchell AL 2019 Analysis of BAFF gene polymorphisms in UK Graves' disease patients. Clinical Endocrinology 90 170-174. (https://doi.org/10.1111/cen.13872)

Lane LC, Cheetham TD, Perros P \& Pearce SHS 2020 New therapeutic horizons for Graves' hyperthyroidism. Endocrine Reviews $\mathbf{4 1}$ bnaa022. (https://doi.org/10.1210/endrev/bnaa022) 
Li K, Du Y, Jiang BL \& He JF 2014 Increased microRNA-155 and decreased microRNA-146a may promote ocular inflammation and proliferation in Graves' ophthalmopathy. Medical Science Monitor 20 639-643. (https://doi.org/10.12659/MSM.890686)

Li CW, Osman R, Menconi F, Concepcion E \& Tomer Y 2020a Cepharanthine blocks TSH receptor peptide presentation by HLA-DR3: therapeutic implications to Graves' disease. Journal of Autoimmunity 108 102402. (https://doi.org/10.1016/j. jaut.2020.102402)

Li HN, Li XR, Du YY, Yang ZF \& Lv ZT $2020 b$ The association between Foxp3 polymorphisms and risk of Graves' disease: a systematic review and meta-analysis of observational studies. Frontiers in Endocrinology 11 392. (https://doi.org/10.3389/fendo.2020.00392)

Limbach M, Saare M, Tserel L, Kisand K, Eglit T, Sauer S, Axelsson T, Syvänen AC, Metspalu A, Milani L, et al. 2016 Epigenetic profiling in CD4+ and CD8+ T cells from Graves' disease patients reveals changes in genes associated with $\mathrm{T}$ cell receptor signaling. Journal of Autoimmunity 67 46-56. (https://doi.org/10.1016/j. jaut.2015.09.006)

Liu J \& Zhang H 2013 1722T/C polymorphism (rs733618) of CTLA-4 significantly associated with systemic lupus erythematosus (SLE): a comprehensive meta-analysis. Human Immunology 74 341-347. (https://doi.org/10.1016/j.humimm.2012.12.009)

Liu R, Ma X, Xu L, Wang D, Jiang X, Zhu W, Cui B, Ning G, Lin D \& Wang S 2012 Differential microRNA expression in peripheral blood mononuclear cells from Graves' disease patients. Journal of Clinical Endocrinology and Metabolism 97 E968-E972. (https://doi. org/10.1210/jc.2011-2982)

Liu W, Wang HN, Gu ZH, Yang SY, Ye XP, Pan CM, Zhao SX, Xue LQ, Xie HJ, Yu SS, et al. 2014 Identification of BACH2 as a susceptibility gene for Graves' disease in the Chinese Han population based on a three-stage genome-wide association study. Human Genetics $\mathbf{1 3 3}$ 661-671. (https://doi.org/10.1007/s00439-013-1404-2)

Lombardi A, Menconi F, Greenberg D, Concepcion E, Leo M, Rocchi R, Marinó M, Keddache M \& Tomer Y 2016 Dissecting the genetic susceptibility to Graves' disease in a cohort of patients of Italian origin. Frontiers in Endocrinology 7 21. (https://doi.org/10.3389/ fendo.2016.00021)

Lowe CE, Cooper JD, Brusko T, Walker NM, Smyth DJ, Bailey R, Bourget K, Plagnol V, Field S, Atkinson M, et al. 2007 Large-scale genetic fine mapping and genotype-phenotype associations implicate polymorphism in the IL2RA region in type 1 diabetes. Nature Genetics 39 1074-1082. (https://doi.org/10.1038/ng2102)

Mao R, Fan Y, Zuo L, Geng D, Meng F, Zhu J, Li Q, Qiao H, Jin Y, Bai J, et al. 2010 Association study between methylenetetrahydrofolate reductase gene polymorphisms and Graves' disease. Cell Biochemistry and Function 28 585-590. (https://doi.org/10.1002/cbf.1694)

Marín-Sánchez A, Álvarez-Sierra D, González O, Lucas-Martin A, SellésSánchez A, Rudilla F, Enrich E, Colobran Oriol R \& Pujol-Borrell R 2019 Regulation of TSHR expression in the thyroid and Thymus May contribute to TSHR tolerance failure in Graves' disease patients via two distinct mechanisms. Frontiers in Immunology 10 1695. (https:// doi.org/10.3389/fimmu.2019.01695)

Martínez-Hernández R, Sampedro-Núñez M, Serrano-Somavilla A, Ramos-Leví AM, de la Fuente H, Triviño JC, Sanz-García A, SánchezMadrid F \& Marazuela M 2018 A microRNA signature for evaluation of risk and severity of autoimmune thyroid diseases. Journal of Clinical Endocrinology and Metabolism 103 1139-1150. (https://doi. org/10.1210/jc.2017-02318)

Mathis D \& Benoist C 2009 Aire. Annual Review of Immunology 27 287-312. (https://doi.org/10.1146/annurev. immunol.25.022106.141532)

Menconi F, Huber A, Osman R, Concepcion E, Jacobson EM, Stefan M, David CS \& Tomer Y 2010 Tg.2098 is a major human thyroglobulin T-cell epitope. Journal of Autoimmunity 35 45-51. (https://doi. org/10.1016/j.jaut.2010.01.004)
Metwalley KA, Farghaly HS, Raafat DM, Ismail AM \& Saied GM 2020 Soluble CD40 ligand levels in children with newly diagnosed Graves' disease. Journal of Clinical Research in Pediatric Endocrinology 12 197201. (https://doi.org/10.4274/jcrpe.galenos.2019.2019.0108)

Muto A, Tashiro S, Nakajima O, Hoshino H, Takahashi S, Sakoda E, Ikebe D, Yamamoto M \& Igarashi K 2004 The transcriptional programme of antibody class switching involves the repressor Bach2. Nature 429 566-571. (https://doi.org/10.1038/nature02596)

Napier C, Mitchell AL, Gan E, Wilson I \& Pearce SH 2015 Role of the $\mathrm{X}$-linked gene GPR174 in autoimmune Addison's disease. Journal of Clinical Endocrinology and Metabolism 100 E187-E190. (https://doi. org/10.1210/jc.2014-2694)

Nemazee D 2017 Mechanisms of central tolerance for B cells. Nature Reviews: Immunology 17 281-294. (https://doi.org/10.1038/ nri.2017.19)

Oaks MK \& Hallett KM 2000 Cutting edge: a soluble form of CTLA-4 in patients with autoimmune thyroid disease. Journal of Immunology 164 5015-5018. (https://doi.org/10.4049/jimmunol.164.10.5015)

Oryoji D, Ueda S, Yamamoto K, Yoshimura Noh J, Okamura K, Noda M, Watanabe N, Yoshihara A, Ito K \& Sasazuki T 2015 Identification of a Hashimoto thyroiditis susceptibility locus via a genome-wide comparison with Graves' disease. Journal of Clinical Endocrinology and Metabolism 100 E319-E324. (https://doi.org/10.1210/jc.20143431)

Pazderska A, Oftedal BE, Napier CM, Ainsworth HF, Husebye ES, Cordell HJ, Pearce SHS \& Mitchell AL 2016 A variant in the BACH2 gene is associated with susceptibility to autoimmune Addison's disease in humans. Journal of Clinical Endocrinology and Metabolism 101 3865-3869. (https://doi.org/10.1210/jc.2016-2368)

Peng H, Liu Y, Tian J, Ma J, Tang X, Yang J, Rui K, Zhang Y, Mao C, Lu L, et al. 2015 Decreased expression of microRNA-125a-3p upregulates interleukin-23 receptor in patients with Hashimoto's thyroiditis. Immunologic Research 62 129-136. (https://doi. org/10.1007/s12026-015-8643-3)

Płoski R, Brand OJ, Jurecka-Lubieniecka B, Franaszczyk M, Kula D, Krajewski P, Karamat MA, Simmonds MJ, Franklyn JA, Gough SC, et al. 2010 Thyroid stimulating hormone receptor (TSHR) intron 1 variants are major risk factors for Graves' disease in three European Caucasian cohorts. PLoS ONE 5 e15512. (https://doi.org/10.1371/ journal.pone.0015512)

Pujol-Borrell R, Gimenez-Barcons M, Marin-Sanchez A \& Colobran R 2015 Genetics of Graves' disease: special focus on the role of TSHR gene. Hormone and Metabolic Research 47 753-766. (https://doi. org/10.1055/s-0035-1559646)

Qi Y, Zhou Y, Chen X, Ye L, Zhang Q, Huang F, Cui B, Lin D, Ning G, Wang W, et al. 2017 Microrna-4443 causes CD4+ T cells dysfunction by targeting TnFr-associated factor 4 in Graves' disease. Frontiers in Immunology 8 1440. (https://doi.org/10.3389/fimmu.2017.01440)

Qin Q, Wang X, Yan N, Song RH, Cai TT, Zhang W, Guan LJ, Muhali FS \& Zhang JA 2015 Aberrant expression of miRNA and mRNAs in lesioned tissues of Graves' disease. Cellular Physiology and Biochemistry 35 1934-1942. (https://doi.org/10.1159/000374002)

Rahman S, Archana A, Jan AT, Dutta D, Shankar A, Kim J \& Minakshi R 2019 Molecular insights into the relationship between autoimmune thyroid diseases and breast cancer: a critical perspective on autoimmunity and ER stress. Frontiers in Immunology 10 344-344. (https://doi.org/10.3389/fimmu.2019.00344)

Ramgopal S, Rathika C, Padma MR, Murali V, Arun K, Kamaludeen MN \& Balakrishnan K 2018 Interaction of HLA-DRB1* alleles and CTLA4 (+ $49 \mathrm{AG})$ gene polymorphism in autoimmune thyroid disease. Gene 642 430-438. (https://doi.org/10.1016/j.gene.2017.11.057)

Ramos-Leví AM \& Marazuela M 2016 Pathogenesis of thyroid autoimmune disease: the role of cellular mechanisms. Endocrinologia $y$ Nutricion 63 421-429. (https://doi.org/10.1016/j.endonu.2016.04.003)

Rapoport B \& McLachlan SM 2007 The thyrotropin receptor in Graves' disease. Thyroid 17 911-922. (https://doi.org/10.1089/thy.2007.0170) 
Roychoudhuri R, Hirahara K, Mousavi K, Clever D, Klebanoff CA, Bonelli M, Sciumè G, Zare H, Vahedi G, Dema B, et al. 2013 BACH2 represses effector programs to stabilize $\mathrm{T}$ reg-mediated immune homeostasis. Nature 498 506-510. (https://doi.org/10.1038/ nature12199)

Sabzevary-Ghahfarokhi M, Shohan M, Shirzad H, Rahimian G, Bagheri N, Soltani A, Deris F, Ghatreh-Samani M \& Razmara E 2018 The expression analysis of Fra-1 gene and IL-11 protein in Iranian patients with ulcerative colitis. BMC Immunology 19 17. (https://doi. org/10.1186/s12865-018-0257-9)

Sakai K, Shirasawa S, Ishikawa N, Ito K, Tamai H, Kuma K, Akamizu T, Tanimura M, Furugaki K, Yamamoto K, et al. 2001 Identification of susceptibility loci for autoimmune thyroid disease to 5q31-q33 and Hashimoto's thyroiditis to 8q23-q24 by multipoint affected sib-pair linkage analysis in Japanese. Human Molecular Genetics 10 1379-1386. (https://doi.org/10.1093/hmg/10.13.1379)

Salvi M, Girasole G, Pedrazzoni M, Passeri M, Giuliani N, Minelli R, Braverman LE \& Roti E 1996 Increased serum concentrations of interleukin-6 (IL-6) and soluble IL-6 receptor in patients with Graves' disease. Journal of Clinical Endocrinology and Metabolism $\mathbf{8 1}$ 2976-2979. (https://doi.org/10.1210/jcem.81.8.8768861)

Sasazuki T, Inoko H, Morishima S \& Morishima Y 2016 Gene map of the HLA region, Graves' disease and Hashimoto thyroiditis, and hematopoietic stem cell transplantation. In Advances in Immunology, pp. 175-249. Elsevier. (https://doi.org/10.1016/bs.ai.2015.08.003)

Schoenmakers EF, Wanschura S, Mols R, Bullerdiek J, Van den Berghe H \& Van de Ven WJ 1995 Recurrent rearrangements in the high mobility group protein gene, HMGI-C, in benign mesenchymal tumours. Nature Genetics 10 436-444. (https://doi.org/10.1038/ ng0895-436)

Shehjar F, Dil A, Misgar RA, Malik SA \& Laway BA 2018 PTPN22 1858 C/T exon polymorphism is not associated with Graves' disease in Kashmiri population. Indian Journal of Endocrinology and Metabolism 22 457-460. (https://doi.org/10.4103/ijem.IJEM_105_18)

Shen L, Huang F, Ye L, Zhu W, Zhang X, Wang S, Wang W \& Ning G 2015 Circulating microRNA predicts insensitivity to glucocorticoid therapy in Graves' ophthalmopathy. Endocrine 49 445-456. (https:// doi.org/10.1007/s12020-014-0487-4)

Silva LM, Chavez J, Canalli MH \& Zanetti CR 2003 Determination of IgG subclasses and avidity of antithyroid peroxidase antibodies in patients with subclinical hypothyroidism-a comparison with patients with overt hypothyroidism. Hormone Research 59 118-124. (https://doi.org/10.1159/000069069)

Simmonds MJ 2011 Evaluating the role of B cells in autoimmune disease: more than just initiators of disease? Advances in Medicine and Biology 28 151-176.

Simmonds MJ, Howson JM, Heward JM, Cordell HJ, Foxall H, CarrSmith J, Gibson SM, Walker N, Tomer Y, Franklyn JA, et al. 2005 Regression mapping of association between the human leukocyte antigen region and Graves disease. American Journal of Human Genetics 76 157-163. (https://doi.org/10.1086/426947)

Simmonds MJ, Heward JM, Carr-Smith J, Foxall H, Franklyn JA \& Gough SC 2006 Contribution of single nucleotide polymorphisms within FCRL3 and MAP3K7IP2 to the pathogenesis of Graves' disease. Journal of Clinical Endocrinology and Metabolism 91 1056-1061. (https://doi.org/10.1210/jc.2005-1634)

Simmonds MJ, Kavvoura FK, Brand OJ, Newby PR, Jackson LE, Hargreaves CE, Franklyn JA \& Gough SC 2014 Skewed X chromosome inactivation and female preponderance in autoimmune thyroid disease: an association study and meta-analysis. Journal of Clinical Endocrinology and Metabolism 99 E127-E131. (https://doi. org/10.1210/jc.2013-2667)

Simpson E 1988 Function of the MHC. Immunology 6427.

Skórka A, Bednarczuk T, Bar-Andziak E, Nauman J \& Ploski R 2005 Lymphoid tyrosine phosphatase (PTPN22/LYP) variant and Graves' disease in a Polish population: association and gene dose-dependent correlation with age of onset. Clinical Endocrinology 62 679-682. (https://doi.org/10.1111/j.1365-2265.2005.02279.x)

Smikle MF, Pascoe RW, Barton E, Morgan O, Christian N, Dowe G, RoyeGreen K, Bailey V \& James O 2001 HLA-DRB3* 0101 is associated with Graves' disease in Jamaicans. Clinical Endocrinology 55 805-808. (https://doi.org/10.1046/j.1365-2265.2001.01414.x)

Smyth D, Cooper JD, Collins JE, Heward JM, Franklyn JA, Howson JM, Vella A, Nutland S, Rance HE, Maier L, et al. 2004 Replication of an association between the lymphoid tyrosine phosphatase locus (LYP/ PTPN22) with type 1 diabetes, and evidence for its role as a general autoimmunity locus. Diabetes 53 3020-3023. (https://doi. org/10.2337/diabetes.53.11.3020)

Stahl PD \& Raposo G 2019 Extracellular vesicles: exosomes and microvesicles, integrators of homeostasis. Physiology 34 169-177. (https://doi.org/10.1152/physiol.00045.2018)

Stanford SM \& Bottini N 2014 PTPN22: the archetypal non-HLA autoimmunity gene. Nature Reviews: Rheumatology 10 602-611. (https://doi.org/10.1038/nrrheum.2014.109)

Stefan M \& Faustino LC 2017 Genetics of thyroid-stimulating hormone receptor - relevance for autoimmune thyroid disease. Frontiers in Endocrinology 8 57. (https://doi.org/10.3389/fendo.2017.00057)

Stefan M, Jacobson EM, Huber AK, Greenberg DA, Li CW, Skrabanek L, Conception E, Fadlalla M, Ho K \& Tomer Y 2011 Novel variant of thyroglobulin promoter triggers thyroid autoimmunity through an epigenetic interferon $\alpha$-modulated mechanism. Journal of Biological Chemistry 286 31168-31179. (https://doi.org/10.1074/jbc.M111.247510)

Štefanić M, Tokić S, Suver-Stević M \& Glavaš-Obrovac L 2019 Expression of TIGIT and FCRL3 is altered in T cells from patients with distinct patterns of chronic autoimmune thyroiditis. Experimental and Clinical Endocrinology and Diabetes 127 281-288. (https://doi. org/10.1055/a-0597-8948)

Sultan CS, Weitnauer M, Turinsky M, Kessler T, Brune M, Gleissner CA, Leuschner F, Wagner AH \& Hecker M 2020 Functional association of a CD40 gene single-nucleotide polymorphism with the pathogenesis of coronary heart disease. Cardiovascular Research 116 1214-1225. (https://doi.org/10.1093/cvr/cvz206)

Swafford D \& Manicassamy S 2015 Wnt signaling in dendritic cells: its role in regulation of immunity and tolerance. Discovery Medicine 19 303-310.

Tolosa E, Roura C, Martí M, Belfiore A \& Pujol-Borrell R 1992 Induction of intercellular adhesion molecule-1 but not of lymphocyte function-associated antigen-3 in thyroid follicular cells. Journal of Autoimmunity 5 119-135. (https://doi.org/10.1016/s08968411(05)80056-3)

Tomer Y 2014 Mechanisms of autoimmune thyroid diseases: from genetics to epigenetics. Annual Review of Pathology 9 147-156. (https://doi.org/10.1146/annurev-pathol-012513-104713)

Tomer Y \& Huber A 2009 The etiology of autoimmune thyroid disease: a story of genes and environment. Journal of Autoimmunity $\mathbf{3 2}$ 231-239. (https://doi.org/10.1016/j.jaut.2009.02.007)

Tomer Y, Barbesino G, Keddache M, Greenberg DA \& Davies TF 1997 Mapping of a major susceptibility locus for Graves' disease (GD-1) to chromosome 14q31. Journal of Clinical Endocrinology and Metabolism 82 1645-1648. (https://doi.org/10.1210/jcem.82.5.4064)

Tomer Y, Barbesino G, Greenberg DA, Concepcion E \& Davies TF 1999 Mapping the major susceptibility loci for familial Graves' and Hashimoto's diseases: evidence for genetic heterogeneity and gene interactions. Journal of Clinical Endocrinology and Metabolism $\mathbf{8 4}$ 4656-4664. (https://doi.org/10.1210/jcem.84.12.6216)

Tomer Y, Menconi F, Davies TF, Barbesino G, Rocchi R, Pinchera A, Concepcion E \& Greenberg DA 2007 Dissecting genetic heterogeneity in autoimmune thyroid diseases by subset analysis. Journal of Autoimmunity 29 69-77. (https://doi.org/10.1016/j. jaut.2007.05.006)

Tomer Y, Hasham A, Davies TF, Stefan M, Concepcion E, Keddache M \& Greenberg DA 2013 Fine mapping of loci linked to autoimmune 
thyroid disease identifies novel susceptibility genes. Journal of Clinical Endocrinology and Metabolism 98 E144-E152. (https://doi. org/10.1210/jc.2012-2408)

Tonacchera M \& Pinchera A 2000 Thyrotropin receptor polymorphisms and thyroid diseases. Journal of Clinical Endocrinology and Metabolism 85 2637-2639. (https://doi.org/10.1210/jcem.85.8.6801)

Torino F, Barnabei A, Paragliola R, Baldelli R, Appetecchia M \& Corsello SM 2013 Thyroid dysfunction as an unintended side effect of anticancer drugs. Thyroid 23 1345-1366. (https://doi.org/10.1089/thy.2013.0241)

Tu Y, Fan G, Zeng T, Cai X \& Kong W 2017 Association between polymorphism within interleukin related genes and Graves' disease: a meta-analysis of 22 case-control studies. Oncotarget 8 98993-99002. (https://doi.org/10.18632/oncotarget.20114)

Tuckermann JP, Pittois K, Partridge NC, Merregaert J \& Angel P 2000 Collagenase-3 (MMP-13) and integral membrane protein 2a (Itm2a) are marker genes of chondrogenic/osteoblastic cells in bone formation: sequential temporal, and spatial expression of Itm2a, alkaline phosphatase, MMP-13, and osteocalcin in the mouse. Journal of Bone and Mineral Research 15 1257-1265. (https://doi. org/10.1359/jbmr.2000.15.7.1257)

Ueda H, Howson JM, Esposito L, Heward J, Snook H, Chamberlain G, Rainbow DB, Hunter KM, Smith AN, Di Genova G, et al. 2003 Association of the T-cell regulatory gene CTLA4 with susceptibility to autoimmune disease. Nature $\mathbf{4 2 3}$ 506-511. (https://doi.org/10.1038/ nature01621)

Valta M, Gazali AM, Viisanen T, Ihantola EL, Ekman I, Toppari J, Knip M, Veijola R, Ilonen J, Lempainen J, et al. 2020 Type 1 diabetes linked PTPN22 gene polymorphism is associated with the frequency of circulating regulatory T cells. European Journal of Immunology $\mathbf{5 0}$ 581-588. (https://doi.org/10.1002/eji.201948378)

Vang T, Congia M, Macis MD, Musumeci L, Orrú V, Zavattari P, Nika K, Tautz L, Taskén K, Cucca F, et al. 2005 Autoimmune-associated lymphoid tyrosine phosphatase is a gain-of-function variant. Nature Genetics 37 1317-1319. (https://doi.org/10.1038/ng1673)

Wallace RB \& Stone MB 2003 Medicare Coverage of Routine Screening for Thyroid Dysfunction. National Academies Press. (https://doi. org/10.17226/10682)

Wang J, Liu L, Ma J, Sun F, Zhao Z \& Gu M 2014 Common variants on cytotoxic T lymphocyte antigen- 4 polymorphisms contribute to type 1 diabetes susceptibility: evidence based on 58 studies. PLOS ONE 9 e85982. (https://doi.org/10.1371/journal.pone.0085982)

Wang B, Shao X, Song R, Xu D \& Zhang JA 2017a The emerging role of epigenetics in autoimmune thyroid diseases. Frontiers in Immunology 8 396. (https://doi.org/10.3389/fimmu.2017.00396)

Wang F, Zhang SJ, Yao X, Tian DM, Zhang KQ, She DM, Guo FF, Zhai QW, Ying H \& Xue Y 2017b Circulating microRNA-1a is a biomarker of Graves' disease patients with atrial fibrillation. Endocrine 57 125-137. (https://doi.org/10.1007/s12020-017-1331-4)

Wang X-X, Wang X-X \& Chen T 2019 Association between the CD40 rs1883832 polymorphism and Graves'disease risk: a meta-analysis. Excli Journal 18 10-20. (https://doi.org/10.17179/excli2017-916)

Wang X, Huang J, Zhang A, Fang C, Ma Q \& Jiang P 2020 Skewed expression profile of receptors for BAFF on peripheral blood $\mathrm{b}$ lymphocytes in Graves' disease. BMC Endocrine Disorders 10 1-7. (https://doi.org/10.21203/rs.3.rs-33595/v2)

Waterhouse P, Penninger JM, Timms E, Wakeham A, Shahinian A, Lee KP, Thompson CB, Griesser H \& Mak TW 1995 Lymphoproliferative disorders with early lethality in mice deficient in Ctla-4. Science 270 985-988. (https://doi.org/10.1126/ science.270.5238.985)

Wawrusiewicz-Kurylonek N, Koper-Lenkiewicz OM, Gościk J, Myśliwiec J, Pawłowski P \& Krętowski AJ 2019 Association of PTPN22 polymorphism and its correlation with Graves' disease susceptibility in Polish adult population - a preliminary study. Molecular Genetics and Genomic Medicine 7 e661. (https://doi. org/10.1002/mgg3.661)
Wellcome Trust Case Control Consortium, Australo-Anglo-American Spondylitis Consortium (TASC), Burton PR, Clayton DG, Cardon LR, Craddock N, Deloukas P, Duncanson A, Kwiatkowski DP, McCarthy MI, et al. 2007 Association scan of 14,500 nonsynonymous SNPs in four diseases identifies autoimmunity variants. Nature Genetics 39 1329-1337. (https://doi.org/10.1038/ng.2007.17)

Wilkin F, Suarez-Huerta N, Robaye B, Peetermans J, Libert F, Dumont JE \& Maenhaut C 1997 Characterization of a phosphoprotein whose mRNA is regulated by the mitogenic pathways in dog thyroid cells. European Journal of Biochemistry 248 660-668. (https://doi. org/10.1111/j.1432-1033.1997.t01-1-00660.x)

Wu GC, Pan HF, Leng RX, Wang DG, Li XP, Li XM \& Ye DQ 2015 Emerging role of long noncoding RNAs in autoimmune diseases. Autoimmunity Reviews 14 798-805. (https://doi.org/10.1016/j. autrev.2015.05.004)

Xue L, Han B, Pan C \& Song H 2014 The Association of SCGB3A2 Polymorphisms with the Risk of Graves' Disease: A Meta-Analysis. Springer. (https://doi.org/10.1007/s12020-013-0021-0)

Yamashita S, Kimura H, Ashizawa K, Nagayama Y, Hirayu H, Izumi M \& Nagataki S 1989 Interleukin-1 inhibits thyrotrophin-induced human thyroglobulin gene expression. Journal of Endocrinology 122 177-183. (https://doi.org/10.1677/joe.0.1220177)

Yan N, Yu YL, Yang J, Qin Q, Zhu YF, Wang X, Song RH \& Zhang JA 2012 Association of interleukin-17A and-17F gene single-nucleotide polymorphisms with autoimmune thyroid diseases. Autoimmunity $\mathbf{4 5}$ 533-539. (https://doi.org/10.3109/08916934.2012.702814)

Yan N, Zhou JZ, Zhang JA, Cai T, Zhang W, Wang Y, Muhali FS, Guan L \& Song RH 2015 Histone hypoacetylation and increased histone deacetylases in peripheral blood mononuclear cells from patients with Graves' disease. Molecular and Cellular Endocrinology $\mathbf{4 1 4}$ 143-147. (https://doi.org/10.1016/j.mce.2015.05.037)

Yan N, Mu K, An XF, Li L, Qin Q, Song RH, Yao QM, Shao XQ \& Zhang JA 2019 Aberrant histone methylation in patients with Graves' disease. International Journal of Endocrinology 20191454617. (https://doi.org/10.1155/2019/1454617)

Yao Q, Wang B, Jia X, Li Q, Yao W \& Zhang JA 2019a Increased human interleukin-32 expression is related to disease activity of Graves' disease. Frontiers in Endocrinology 10 613. (https://doi.org/10.3389/ fendo.2019.00613)

Yao Q, Wang X, He W, Song Z, Wang B, Zhang J \& Qin Q 2019 b Circulating microRNA-144-3p and miR-762 are novel biomarkers of Graves' disease. Endocrine 65 102-109. (https://doi.org/10.1007/ s12020-019-01884-2)

Yin X, Latif R, Bahn R, Tomer Y \& Davies TF 2008 Influence of the TSH receptor gene on susceptibility to Graves' disease and Graves' ophthalmopathy. Thyroid 18 1201-1206. (https://doi.org/10.1089/ thy.2008.0098)

Yin X, Latif R, Bahn R \& Davies TF 2012 Genetic profiling in Graves' disease: further evidence for lack of a distinct genetic contribution to Graves' ophthalmopathy. Thyroid 22 730-736. (https://doi. org/10.1089/thy.2012.0007)

Yoneda M, Xu L, Kajiyama H, Kawabe S, Paiz J, Ward JM \& Kimura S 2016 Secretoglobin superfamily protein SCGB3A2 alleviates house dust mite-induced allergic airway inflammation in mice. International Archives of Allergy and Immunology 171 36-44. (https://doi. org/10.1159/000450788)

Yuan M, Wei L, Zhou R, Bai Q, Wei Y, Zhang W \& Huang Y 2016 Four FCRL3 gene polymorphisms (FCRL3_3,_5, _6, _8) confer susceptibility to multiple sclerosis: results from a case-control study. Molecular Neurobiology 53 2029-2035. (https://doi.org/10.1007/ s12035-015-9149-7)

Yui MA \& Rothenberg EV 2014 Developmental gene networks: a triathlon on the course to T cell identity. Nature Reviews: Immunology 14 529-545. (https://doi.org/10.1038/nri3702)

Zamani M, Spaepen M, Bex M, Bouillon R \& Cassiman JJ 2000 Primary role of the HLA class II DRB1* 0301 allele in Graves disease. 
American Journal of Medical Genetics 95 432-437. (https://doi. org/10.1002/1096-8628(20001218)95:5<432::aid-ajmg5>3.0.co;2-7)

Zeitlin AA, Heward JM, Newby PR, Carr-Smith JD, Franklyn JA, Gough SC \& Simmonds MJ 2008 Analysis of HLA class II genes in Hashimoto's thyroiditis reveals differences compared to Graves' disease. Genes and Immunity 9 358-363. (https://doi.org/10.1038/ gene.2008.26)

Zhang XH, Shen M, Liu L, Li FM, Hu PC, Hua Q, Zhang J, Pang LN, Lu HW, Wang ZM, et al. 2017 Association analysis of single nucleotide polymorphisms in C1QTNF6, RAC2, and an intergenic region at 14q32. 2 with Graves' disease in Chinese Han population. Genetic Testing and Molecular Biomarkers 21 479-484. (https://doi. org/10.1089/gtmb.2017.0009)

Zhang Q, Liu S, Guan Y, Chen Q, Zhang Q \& Min X 2018 RNaseT2, GPR174, and PTPN22 gene polymorphisms are related to the risk of liver damage associated with the hyperthyroidism in patients with Graves' disease. Journal of Clinical Laboratory Analysis 32 e22258. (https://doi.org/10.1002/jcla.22258)

Zhang D, Qiu X, Li J, Zheng S, Li L \& Zhao H 2019 MiR-23a-3pregulated abnormal acetylation of FOXP3 induces regulatory $\mathrm{T}$ cell function defect in Graves' disease. Biological Chemistry 400 639-650. (https://doi.org/10.1515/hsz-2018-0343)
Zhao SX, Pan CM, Cao HM, Han B, Shi JY, Liang J, Gao GQ, Peng YD, Su Q, Chen JL, et al. 2010 Association of the CTLA4 gene with Graves' disease in the Chinese Han population. PLoS ONE 5 e9821. (https://doi.org/10.1371/journal.pone.0009821)

Zhao SX, Xue LQ, Liu W, Gu ZH, Pan CM, Yang SY, Zhan M, Wang HN, Liang J, Gao GQ, et al. 2013 Robust evidence for five new Graves' disease risk loci from a staged genome-wide association analysis. Human Molecular Genetics 22 3347-3362. (https://doi.org/10.1093/ $\mathrm{hmg} / \mathrm{ddt} 183$

Zhao F, Wu L, Wang Y, Liu L, Yang F, Sun Y, Jiao X, Bao L, Chen P, Liang Q, et al. 2019 Dihydrotestosterone regulates oxidative stress and immunosuppressive cytokines in a female BALB/c mouse model of Graves' disease. Autoimmunity 52 117-125. (https://doi.org/10.108 $0 / 08916934.2019 .1621857)$

Zheng L, Wang X, Xu L, Wang N, Cai P, Liang T \& Hu L 2015 Foxp3 gene polymorphisms and haplotypes associate with susceptibility of Graves' disease in Chinese Han population. International Immunopharmacology 25 425-431. (https://doi.org/10.1016/j.intimp.2015.02.020)

Zimmermann MB, Gizak M, Abbott K, Andersson M \& Lazarus JH 2015 Iodine deficiency in pregnant women in Europe. Lancet. Diabetes and Endocrinology 3 672-674. (https://doi.org/10.1016/ S2213-8587(15)00263-6)

Received in final form 28 October 2020

Accepted 2 December 2020

Accepted Manuscript published online 10 December 2020
(C) 2021 Society for Endocrinology Published by Bioscientifica Ltd. Printed in Great Britain 